(C) <2021>. This manuscript version is made available under the CC-BY-NC-ND 4.0 license http://creativecommons.org/licenses/by-nc-nd/4.0/

The definitive publisher version is available online at https://doi.org/ $\underline{10.1016 / j . r s e r .2021 .111354}$ 


\title{
Identification and characterization of decision-making factors over industrial energy efficiency measures in electric motor systems
}

\author{
Accordini, D. 1, *, Cagno, E. ${ }^{1}$, Trianni, A. ${ }^{2}$ \\ ${ }^{1}$ Department of Management, Economics and Industrial Engineering, Politecnico di Milano, P.za Leonardo da \\ Vinci, Milan 20133, Italy; enrico.cagno@polimi.it \\ ${ }^{2}$ School of Information, Systems and Modelling, Faculty of Engineering and IT, University of Technology \\ Sydney, 81 Broadway, Ultimo 2007, Australia; andrea.trianni@uts.edu.au \\ * = corresponding author details, davide.accordini@ polimi.it; Tel.: +39-348-148-0926
}

\begin{abstract}
Energy efficiency measures in electric motor systems are scarcely implemented, and previous literature has largely overlooked the characterizing factors responsible for their adoption in industrial operations. The present study, after a comprehensive literature review, aims at supporting research by offering a framework for the identification of the factors that should be assessed when considering the adoption of electric motor systems' energy efficiency measures. The proposed factors are clustered in ten categories, namely: contextual factors, compatibility, economy, energy savings, production-related factors, operations-related factors, synergies, complexity, personnel and additional technical factors. After a preliminary empirical validation, the proposed framework has been applied in a selected sample of manufacturing firms. Findings show that factors more closely related to the firm's production and operations result most critical for the adoption of energy efficiency measures. However, the adoption process is also deeply influenced by their complexity or compatibility to the specific context application, therefore calling for an exhaustive assessment. The adoption of the framework would have reversed some firm's decisions over the initial uptake of EEMs that proved to have critical issues for their implementation. Therefore, the proposed framework provides additional support and further value to decision-makers especially for non-energy intensive firms, where the impact on non-energy production resources becomes more important, and SME usually present greater difficulties for a holistic assessment of EEMs. The study concludes with main implications for research and policy-making from the present study as well as suggestions for future research.
\end{abstract}

\section{Highlights}

- Novel framework of characterizing factors for electric motor systems in industry.

- Thorough assessment of energy efficiency measures in electric motor systems.

- Decision-making factors for the adoption of energy efficiency measures.

- Impacts of energy efficiency on firms' production resources and operations. 


\section{Keywords}

Energy Efficiency; Electric Motor Systems; Energy Efficiency Measures; Non-Energy Benefits; Decision Making; Characterizing factors.

Word Count: 5571 words

\section{List of Abbreviations}

EMS Electric motor systems

EEMs Energy efficiency measures

NEBs Non-energy benefits

\section{Introduction}

With energy consumption projected to grow by about $50 \%$ between 2018 and 2050 [1], the commitment towards industrial energy efficiency plays a critical role [2,3]. A major share of electric energy consumption is attributable to electric motor systems (EMS) [4,5] thanks to their widespread diffusion in a number of industrial applications and purposes. Despite the existence of minimum efficiency mandatory standards in most of the Countries for new motors, about $70 \%$ of the total energy consumed by motors comes from unregulated (IE0) or low-efficiency devices (IE1) [2]. Moreover, reviews show that EMS are broader than the motor itself, with a variety of energy efficiency measures (EEMs) [6], still presenting a largely untapped energy efficiency potential [7]. Despite EEMs in EMS can be easily implemented and with high estimated investment returns [2,8], their implementation rate is still low [9]. Therefore, what could appear at first sight as a low hanging fruit may hide the understanding of a much more complex situation, where the lack of information and specific characteristics of EEMs - together with the potential disruption coming from their adoption - could represent higher barriers jeopardizing their implementation $[10,11]$. Hence, a mere techno-economic feasibility analysis is insufficient to capture the implications of effectively placing an EEM into the operations. Further, research has been so far limited to highlight some relevant characteristics of EEMs in general (e.g., the knowledge required for the planning and implementation of a general EEM or its diffusion progress and sectorial applicability [12,13]). However, considering EEMs within EMS, the necessary detail to effectively guide decision-makers in the understanding of the distinctive features driving the adoption [14,15] is still lacking. Unfortunately, literature has just preliminarily explored the impacts generated by the adoption of EEMs on a firm's production resources and activities, such as the variations of productivity and production quality. Yet, research has not sufficiently disentangled the multiple impacts on the operations and the working environment.

To contribute to the discussion by addressing the aforementioned research gaps, a novel framework has been specifically designed. The framework could also guide industrial decision-makers and policy-makers in selecting the most appropriate means to promote EEMs in EMS. The remainder of the paper is structured as follows: in Section 2, the extant literature on factors crucial for decision-making over EEMs in EMS is extensively 
reviewed, followed by the presentation of the new framework (Section 3). In Section 4, the research method used to empirically validate the framework is detailed and the results are explained in Section 5. After the discussion (Section 6), concluding remarks are provided in Section 7.

\section{Literature background}

Previous research has investigated the characteristics of EEMs in general terms. Fleiter et al. [12] designed a framework of factors characterising EEMs organized according to the categories of relative advantage, technical context and information context. By considering aspects such as the relative advantage or the complexity of an EEM [16], the study represents one of the first attempts to encompass into the analysis of EEMs some elements referring to the diffusion of innovation [17]. Complexity has been acknowledged as an important element that is an essential characteristic linked to the type of investment [18]; similarly, Sandberg and Söderstrom [19] have distinguished between replacements and development investments, the latter being characterized by a good level of profitability but also with a higher risk of greater losses. Fleiter et al. [12] have addressed complexity through the factor type of modification and scope of impact, also taking inspiration from earlier literature [20]. Mills et al. [21] have pointed out the inverse relationship between technical complexity of EEMs, thus uncertainty on the results and their adoption rate, confirming earlier findings by Tornatzky and Klein [17]. The complexity of an EEM is also related to the expertise required during the various stages of the adoption [12], thus on training activities, considered critical also for improving the awareness towards energy efficiency [22,23]. Nonetheless, given the wide skill range required, firms often lack adequate personnel [24,25].

Several studies elaborated on Fleiter et al. [12], reviewing their framework and proposing novel sets of factors. Trianni et al. [13] have kept information regarding the complexity of an EEM including e.g., the ease of implementation, the likelihood of success/acceptance and the corporate involvement required for the adoption. Regarding the economic dimension, implementation costs are deemed as crucial especially in the case of small and medium-sized enterprises (SMEs) [26,27] and potentially more critical than the payback period for EEMs adoption rate [28]. The payback period has been acknowledged as a common indicator to assess investments profitability [29,30]. Cooremans [31] has highlighted the importance of analysing EEMs not only at the operations level but from a strategic perspective. On the other hand, Roberts and Ball [32] have focused on timerelated technical characteristics, i.e., implementation time and implementation pace, as well as considering some basic contextual information, such as the physical location where the sustainable manufacturing practices is placed.

Other scholars have enriched the analysis by offering additional information related to consequences on the production and the firms' operations stemming from the adoption of EEMs. In some cases, energy savings are not the most valuable result according to the final users (e.g., $[33,34]$ ) and therefore should just be part of the equation rather than the ultimate objective [35]. In literature, such advantages (e.g., lower maintenance requirements, increased productivity, reduced waste and emissions) are generally known as non-energy benefits 
(NEBs) [13]. Likewise, EEMs may also have negative impacts on the system, i.e., non-energy disbenefits or losses [36] (e.g., production disruption [37]). Hence, both benefits and losses should be equally acknowledged for wise decision-making [38].

Among NEBs, production and productivity improvements are generally a strong driver for the adoption of EEMs [35]. Despite being usually perceived as a direct benefit of EEMs [39,40] productivity may also be enhanced indirectly, e.g., through improved working conditions positively stimulating operators [39]. On the other hand, unnecessary downtimes should be avoided [19] as potentially leading to disruptions in production [37], particularly critical for heavy capital-intensive sectors and energy-intensive sectors based on continuing production [10,41]. The adoption of an EEM may also bring improved product quality $[42,43]$, measurable by the scraps and reworks reduction [33,44], leading in turn to improved customer satisfaction [35] which may be even more important than a reduction in production costs for decision-makers [23].

Moreover, productivity could be affected by variations in process control $[45,46]$ and equipment conditions and reliability [39,42]. The latter, in turn, may be strongly affected by the adoption of EEMs, together with the lifetime of the devices $[47,48]$. Referring to the operation and maintenance dimension, many authors pointed out a reduction in motor size [38] or the number of needed devices [49], with a consequent cut in labour requirements and engineering controls [39], but an increase in capacity may occur as well [50,51]. However, authors note the importance of thoroughly assessing the amount of additional indirect costs such as production losses arisen due to production shutdowns [52,53]

The benefits of adopting EEMs can extend to the entire working environment, e.g., by improving the internal temperature [52,54], air quality [45,55] or lighting [56,57], or even by reducing the noise level [58,59], with increased workers' productivity [39], comfort [38], health and safety [60,61]. The impact on the external environment may be important as well, in terms of emissions and waste [13,20] with a potential improvement of firm's image [62] and its public relations [35, also in light of current or future compliance with regulations and environmental targets $[13,63]$.

Among a variety of technologies, EMS are extensively adopted in industrial firms in a countless range of both core production and ancillary processes and have been widely investigated by research (e.g., $[13,64,65])$. Despite a wealth of industrial literature, previous contributions are mostly limited to an analysis of their technical features (e.g., [66,67]), with just little research exploring a limited number of NEBs stemming from the adoption of EEMs in EMS, by addressing motor units and control systems [35].

As summarised in Table 1, earlier research describing EEMs' features $[13,68]$ has not accounted for the entirety of factors potentially relevant for decision-making purposes. Furthermore, the focus on specific technologies and EEMs is crucial since it allows relevant factors to emerge, as shown by previous research on EEMs in compressed air systems [69]. It is therefore clear that a study encompassing the complete set of factors that might influence the adoption of EMS EEMs is lacking. In fact, the contextual dimensions in which EMS are 
called to operate remain still unexplored, both in terms of business-related factors (such as firm size and sector $[41,70])$, operating context, as well as its interactions with the surrounding environment.

The framework is intended to facilitate the complex process of industrial decision-making over EEMs in EMS. The need for such a tool comes from the complexity of the task to be performed, influenced by both the surrounding working environment, with its multiple and varying dynamics and constraints, and the subjectivity and capabilities of the single decision-maker [71,72], whose perspective filter the entire study.

\section{Table 1}

Synthesis of factors used in literary studies to describe EEMs.

\begin{tabular}{|c|c|c|c|}
\hline Factors & References & Factors & References \\
\hline Corporate involvement & {$[13,43,73,74]$} & $\begin{array}{l}\text { Perception, collaboration with } \\
\text { clients, suppliers, competitors }\end{array}$ & {$[36,43]$} \\
\hline Nature & [36] & $\begin{array}{l}\text { Increased communication between } \\
\text { department and levels within the } \\
\text { firm }\end{array}$ & [74] \\
\hline Activity type & {$[12,13,32,75]$} & Workers' productivity & {$[53,76-80]$} \\
\hline Scope of impact & {$[12]$} & Labour savings (or labour cost) & $\begin{array}{l}{[33-} \\
35,37,42,47,49,51,53,55,57,61,64,77, \\
81-84]\end{array}$ \\
\hline Targeted area & {$[36]$} & Reduction in labour requirement & $\begin{array}{l}{[31,34,38,39,45-47,49,50,69,77,83-} \\
88]\end{array}$ \\
\hline Extension of impact & {$[36]$} & Indirect effects & {$[13]$} \\
\hline $\begin{array}{l}\text { Independency from other } \\
\text { components or EEMs }\end{array}$ & {$[75]$} & Larger product range & [53] \\
\hline EEM location & {$[32]$} & Flexibility in production & {$[50,53,80,87]$} \\
\hline Accessibility & [75] & Material handling and movement & {$[61,85]$} \\
\hline Diffusion progress & {$[12,32,43,73]$} & Raw material and fuel & $\begin{array}{l}{[13,31,33-35,42,46,47,50-} \\
53,55,59,61,65,69,73,80-83,85-93]\end{array}$ \\
\hline Check-up frequency & [13] & Reduced water consumption & $\begin{array}{l}{[37,38,42,47,48,53,55,57,58,61,77,78,} \\
83-85,89,94,95]\end{array}$ \\
\hline Complexity & {$[16,17,75]$} & Reliability in production & $\begin{array}{l}{[31,33-35,39,42,45-49,51-} \\
53,55,64,69,81,83,84,86,96-99]\end{array}$ \\
\hline Trialability & {$[16,17]$} & Availability & [98] \\
\hline Duration of the impacts & {$[32,36]$} & Unscheduled downtime & {$[50,53,59,80,87,98]$} \\
\hline Resilience & [36] & $\begin{array}{l}\text { Reduced cost of production } \\
\text { disruption }\end{array}$ & [82] \\
\hline Maintainability of the impacts & {$[36]$} & Length of implementation & [32] \\
\hline Stability of the impacts & {$[36]$} & Sourcing strategy & {$[32]$} \\
\hline $\begin{array}{l}\text { Timescale (peak and frequency of } \\
\text { exploitation of the impacts) }\end{array}$ & {$[36]$} & $\begin{array}{l}\text { Lower or different maintenance (or } \\
\text { maintenance cost) }\end{array}$ & $\begin{array}{l}{[13,34,35,37,42,46-53,55,57-} \\
61,64,65,69,74-87,89,91,94-96,100- \\
103]\end{array}$ \\
\hline $\begin{array}{l}\text { Knowledge for planning, } \\
\text { implementation and use }\end{array}$ & {$[12,13,32,43,75,77,85,104]$} & Wear and tear on equipment & $\begin{array}{l}{[31,39,45,47,51-53,65,74-} \\
76,81,83,84,89]\end{array}$ \\
\hline $\begin{array}{l}\text { Increased knowledge of the } \\
\text { process or operation }\end{array}$ & {$[74]$} & Extended lifetime of the equipment & $\begin{array}{l}{[12,34,37,46-} \\
48,51,53,57,60,61,64,69,76,79,81- \\
84,86,89,94,98,102,103]\end{array}$ \\
\hline Additional space & $\begin{array}{l}{[31,39,45,47,49-} \\
51,53,79,81,83,84,87,101]\end{array}$ & Improved process control & {$[31,38,39,45-47,51,53,81,83,96]$} \\
\hline Likelihood of success & {$[13,105]$} & Reduced operational cost & $\begin{array}{l}13,34,35,47,51,52,60,61,64,65,73,74, \\
76,78,79,81,83,85,89,91,94-96]\end{array}$ \\
\hline Compatibility & {$[16,17,75,98]$} & Logistic benefits & {$[47,82]$} \\
\hline $\begin{array}{l}\text { Adaptability to different } \\
\text { conditions }\end{array}$ & {$[75]$} & Real time data & [59] \\
\hline Synergies & {$[36,75]$} & $\begin{array}{l}\text { Generation of KPI for comparison } \\
\text { within the firm }\end{array}$ & [74] \\
\hline Distance to the core process & {$[12,13,31,80,91,98]$} & $\begin{array}{l}\text { Simplification or automation of } \\
\text { customs procedures }\end{array}$ & [53] \\
\hline $\begin{array}{l}\text { Sectoral applicability (process- } \\
\text { related, cross-cutting) }\end{array}$ & {$[12]$} & New contracts and design processes & [79] \\
\hline Firm size & {$[49,53,60,73,99]$} & New service provider & [79] \\
\hline
\end{tabular}




\begin{tabular}{|c|c|c|c|}
\hline Factors & References & Factors & References \\
\hline Energy intensity & {$[81,99]$} & $\begin{array}{l}\text { Obtain sustainability or energy } \\
\text { certification }\end{array}$ & {$[43,79]$} \\
\hline Sector & {$[53,61,73,95]$} & Increased sales levels & {$[34,43,46,53,61,64,74,85,91,103]$} \\
\hline Motor numerosity & [89] & $\begin{array}{l}\text { Improved public image, brand } \\
\text { reputation }\end{array}$ & $\begin{array}{l}{[39,43,45-} \\
47,50,51,53,61,64,69,73,77,81- \\
84,86-88,90,98,99,104]\end{array}$ \\
\hline Motor size & {$[49,98]$} & Improved competitiveness & $\begin{array}{l}{[43,47,50,51,73,74,81,83,84,87,91-} \\
93,96,99]\end{array}$ \\
\hline Motor type & [98] & Increased market share & {$[61,64,91,104]$} \\
\hline Working hours & [98] & New markets & {$[43,104]$} \\
\hline Torque and speed requirements & [98] & $\begin{array}{l}\text { Contribution to the firm's vision or } \\
\text { strategy }\end{array}$ & [53] \\
\hline Saving strategy & {$[13]$} & Reduced currency risk & {$[47,82]$} \\
\hline Amount of saved energy & {$[13,33,51,53,57,65,75,81,83,89,98,105]$} & $\begin{array}{l}\text { Reduced risk (legal, energy, CO2, } \\
\text { water price, energy supply, } \\
\text { commercial) }\end{array}$ & {$[31,44,53,77,78,80,81,83,98,99,104]$} \\
\hline Improve energy management & {$[74,103]$} & $\begin{array}{l}\text { Future change of energy price } \\
\text { (volatility) }\end{array}$ & {$[61,79,88,92,93,104]$} \\
\hline Improved lighting & $\begin{array}{l}{[34,37,39,45-48,50-53,56,57,60,81-} \\
84,87,102]\end{array}$ & $\begin{array}{l}\text { Reduced volatility of business } \\
\text { results }\end{array}$ & {$[61]$} \\
\hline Improved air quality & $\begin{array}{l}{[31,34,37,39,42,45-48,50-53,55-} \\
57,60,64,69,74-76,78,79,81-84,86- \\
89,92,93,96,106]\end{array}$ & Decreased liability & {$[31,39,45,47,51,53,81,83,90,106]$} \\
\hline $\begin{array}{l}\text { Better air flow (production, } \\
\text { ancillary) }\end{array}$ & {$[37,47,53,57,59]$} & Implementation cost & {$[12,13,17,32,43,60,75,94,98]$} \\
\hline Vibration (and cavitation) & {$[59,76,89]$} & Premium price & [61] \\
\hline Reduced noise level & $\begin{array}{l}31,34,37-39,42,45-48,50- \\
53,55,56,58,59,69,74-76,81- \\
84,87,95,101,102,107]\end{array}$ & Transaction cost & {$[12,32]$} \\
\hline $\begin{array}{l}\text { Improved temperature control (of } \\
\text { working environment) }\end{array}$ & $\begin{array}{l}{[31,39,45-47,50,52-54,65,74,76,79,82-} \\
84,87,106]\end{array}$ & $\begin{array}{l}\text { Acquisition of complementary } \\
\text { technology }\end{array}$ & [43] \\
\hline Reduced need for cooling & $\begin{array}{l}{[31,37,39,42,45-} \\
47,51,53,55,57,65,69,81- \\
84,86,89,96,99]\end{array}$ & $\begin{array}{l}\text { Reduced interest cost on capital } \\
\text { investment }\end{array}$ & $\begin{array}{l}{[31,34,39,42,45,47,49,51,53,55,61,69,} \\
77,81,83,84,86,88,105]\end{array}$ \\
\hline Better aesthetics & {$[34,37,47,48,57,60,83,101,102,107]$} & $\begin{array}{l}\text { Reduced or eliminated rental } \\
\text { equipment cost (or increased renting } \\
\text { revenue) }\end{array}$ & $\begin{array}{l}{[33,42,48,49,53,55,61,79,80,85,106,1} \\
08]\end{array}$ \\
\hline Reduced ancillary operations & {$[77,83]$} & $\begin{array}{l}\text { Reduced or eliminated demand } \\
\text { charges }\end{array}$ & {$[34,42,48,55,61,77]$} \\
\hline Reduced operating units & [54] & Increased facility or asset value & $\begin{array}{l}{[44,47,48,50,51,53,61,64,77,79,81,83,} \\
87,88,92,93,103,108]\end{array}$ \\
\hline Reduced backup units & [49] & Pay-back & {$[12,13,17,32,43,53,61,65,75,91,94,97]$} \\
\hline Improved ease of system operation & [49] & IRR & {$[32]$} \\
\hline Improved worker morale & $\begin{array}{l}{[31,39,45-} \\
47,50,51,53,57,61,64,69,79,81- \\
84,86,87,104]\end{array}$ & Cash-flow & [36] \\
\hline $\begin{array}{l}\text { Increased workers safety (reduced } \\
\text { incidents) }\end{array}$ & $\begin{array}{l}31,33-35,37,38,42,44,46-53,55- \\
58,60,61,64,69,75,76,79- \\
84,87,94,95,104,106,108,109]\end{array}$ & Shareholder return & {$[61]$} \\
\hline Greater comfort & $\begin{array}{l}{[13,31,34,37,38,42,44,46-48,50-53,55-} \\
58,60,61,64,74,76-79,81-84,87,88,92- \\
96,99,101,103,104,106-110]\end{array}$ & Taxes & {$[33,43,48,56,77,79,99,100,107]$} \\
\hline $\begin{array}{l}\text { Vapor, moisture, mould (working } \\
\text { environment) }\end{array}$ & {$[50,87]$} & $\begin{array}{l}\text { Reduced fines related to emission } \\
\text { exceedances }\end{array}$ & $\begin{array}{l}{[33,35,43,47,51-} \\
53,61,65,77,79,81,83-85,88,94]\end{array}$ \\
\hline Reduced smell (from leaking oil) & {$[50,64,87]$} & $\begin{array}{l}\text { Achieved rebate, incentives, } \\
\text { subsidies }\end{array}$ & {$[31,42,55,77,79,90,99]$} \\
\hline $\begin{array}{l}\text { Reduced } \mathrm{CO}, \mathrm{CO} 2, \mathrm{NOX}, \mathrm{SOX} \\
\text { emissions }\end{array}$ & $\begin{array}{l}{[31,34,39,42,45-} \\
48,50,52,53,55,60,64,65,69,73,79- \\
82,84,86-93,95,100,105,108-111]\end{array}$ & Lower cost of treatment chemicals & {$[42,47,55,61,89]$} \\
\hline $\begin{array}{l}\text { Reduced dust emissions (and } \\
\text { ashes) }\end{array}$ & $\begin{array}{l}31,39,42,45-48,50- \\
53,55,69,83,84,87,100,110] \\
\end{array}$ & $\begin{array}{l}\text { Reduced planning, legal, } \\
\text { administrative, procurement cost }\end{array}$ & {$[77,85]$} \\
\hline Reduced waste & $\begin{array}{l}{[31,34,35,37-39,42,45-48,50-} \\
53,55,58,64,69,74,77,78,80-84,86,87]\end{array}$ & Stimulate economic development & $\begin{array}{l}{[48,60,61,78,88,91-} \\
93,95,100,107,109]\end{array}$ \\
\hline Use of waste heat, fuel, gas & {$[31,39,45,47,52,53,82,83]$} & Turno ver of energy efficiency goods & {$[92,93]$} \\
\hline Environmental & $\begin{array}{l}{[13,38,42,48,50,55,57,58,61,74,78,87,9} \\
0,92-94,102,103]\end{array}$ & Renewable energy sources target & {$[92,93]$} \\
\hline Production, productivity & $\begin{array}{l}13,16,17,31,33-35,37,39,42,44- \\
49,51,53,55-57,59-61,64,65,69,73,79- \\
84,86,88-96,99,101-104,112]\end{array}$ & Rebound effect & {$[88]$} \\
\hline
\end{tabular}




\begin{tabular}{|c|c|c|c|}
\hline Factors & References & Factors & References \\
\hline Increased capacity & {$[33,35,47,50,51,53,81,83,87,91]$} & Infrastructure & {$[48,100]$} \\
\hline Shorter process cycle time & $\begin{array}{l}{[31,39,42,45-47,51-} \\
53,55,57,61,69,74,80,81,83,86,105]\end{array}$ & Create jobs, employment & $\begin{array}{l}{[37,44,48,60,61,74,77,88,91-} \\
93,95,100,107-109]\end{array}$ \\
\hline Stock and lead time & [98] & Poverty alleviation & {$[44,61,88,92-94,100,106-109]$} \\
\hline $\begin{array}{l}\text { Changes in the organization of } \\
\text { production }\end{array}$ & [43] & Innovation & {$[92,93,104]$} \\
\hline Product quality & $\begin{array}{l}{[31,33-35,37,39,42,45-47,50-} \\
53,55,57,59,61,64,65,69,73,74,76,80- \\
87,89,96,98,99,105]\end{array}$ & Consumer surplus & [44] \\
\hline Service quality & [98] & Climate change & {$[44,90,91]$} \\
\hline $\begin{array}{l}\text { Improved customer satisfaction, } \\
\text { change orders, warranty claim }\end{array}$ & $\begin{array}{l}{[33-} \\
35,37,47,48,51,53,57,58,60,64,76,80,81 \\
, 83,90,108]\end{array}$ & Energy security & $\begin{array}{l}{[31,44,48,50,61,73,78,83,87,88,90,92,} \\
93,99]\end{array}$ \\
\hline $\begin{array}{l}\text { Reduced customer service cost (for } \\
\text { better quality) }\end{array}$ & {$[53]$} & Public budgets & {$[88,91-93]$} \\
\hline
\end{tabular}

\section{A novel framework for decision-making factors on EEMs in EMS}

To design a complete framework targeting EEMs in EMS, common features have been identified through the technical description of EEMs in EMS, as recent research suggests [113]. By taking inspiration from the extant literature, features have been clustered to define a novel set of factors through a synthesis process. The approach aims at offering a holistic perspective over the analysis, by encompassing the broad set of impacts on the operations and the other production resources of a firm as well as the contextual dimension in which EEMs are embedded. The definition of the factors is followed by a process of clustering into categories and sub-categories, strongly enhancing the applicability of the framework, also for a potential deployment as an assessment tool (Cagno et al. [114]). A total of 57 factors have been defined and organized in 10 categories, namely: (i) contextual factors, (ii) compatibility, (iii) economy, (iv) energy savings, (v) production-related factors, (vi) operations-related factors, (vii) synergies, (viii) complexity, (ix) personnel and (x) additional technical factors.

Since the framework is designed to support industrial decision-makers, an additional advantage is provided by the indication of the adoption phase addressed by each factor. The distinction between implementation (I) and service (S) phase [36] can give more accurate insights, enabling the optimization of the resources available for the firms. Details over the categories, the sub-categories and factors are reported in Table 2.

\subsection{Contextual factors}

Contextual factors provide a broader picture of the applications in which the EEMs may operate. Indeed, the built-in motors' characteristics and the operating context influence the possible impacts of EEMs on the system and may direct the choice on the most appropriate EEMs, by limiting the number of opportunities. This category includes 6 factors, namely: (i) motor model, (ii) motor size, (iii) motors number, (iv) working hours, (v) process focus and (vi) application load.

\subsection{Compatibility}

Taking inspiration from Rogers [16], compatibility defines the capability for EEMs to adapt in an already organized system and to establish a positive engagement with existing operating conditions and devices. This category is structured with two sub-categories, namely: (i) load and (ii) system. The load sub-category refers to 
the compatibility of EEMs to the specific application requirements, by including load compatibility and adaptability to different conditions. The system sub-category refers to (i) the compatibility of an EEM to the physical environment in which it operates; and (ii) the possible reduction in layout flexibility.

\subsection{Economy}

The economy category encompasses several common factors for the assessment of EEMs' economic figures, by including: (i) initial implementation costs; (ii) total adoption costs; (iii) adoption costs of mandatory secondary devices; (iv) adoption cost of additional optimisation devices; (v) financial exposure; (vi) monetary savings and (vii) pay-back time.

\subsection{Energy savings}

Reduced energy consumption is the first perceivable impact coming from the adoption of an EEM [18,35].

\subsection{Production-related factors}

This category describes the production-related impacts on a firm stemming from the EEMs adoption, including variations in ancillary processes with indirect impact on productivity (e.g., operators productivity improved thanks to improved working conditions [39] obtained through the optimization of an ancillary system such as air conditioning). The same holds also for production processes, whose variations may have a dual impact on the production area, both direct and indirect. This category is organized into global and local sub-categories. The global sub-category analyses through six factors how the total of EMS installed in a plant affects its productionrelated activities, directly and indirectly, in terms of: (i) productivity; (ii) production quality and (iii) production costs. The local sub-category rather focuses on single EMS, describing its performance variation and condition with potential impact on production-related factors, by including: (i) setup time; (ii) reliability of the equipment; (iii) downtime for maintenance and repairs; (iv) downtime for implementation; (v) equipment lifetime and (vi) process control.

\subsection{Operations-related factors}

The category describes the impact EEMs may have on factors related to operations. Different perspectives are introduced, shifting the focus from the conditions of the single EMS to a holistic analysis of the working and the broader external environment. This includes three sub-categories: (i) motor conditions, (ii) working environment and (iii) external environment. Concerning motor conditions, the impacts coming from the adoption of EEMs are perceived by analysing the operating parameters of the equipment, including: (i) temperature; (ii) vibrations; (iii) power quality; and (iv) air quality. Further, the impacts coming from the adoption of EEMs on the working environment are assessed in terms of: (i) noise; (ii) environmental temperature; (iii) environmental vibrations; (iv) health and safety; and (v) air quality. Impacts on the external environment are assessed through changes in (i) waste; and (ii) emissions. 


\subsection{Synergies}

During the adoption, industrial decision-makers may identify synergies between different EEMs and coordinate their action to gain advantages [36] (e.g., avoiding multiple shutdowns of the plant by scheduling the implementation of several EEMs during maintenance activities).

\subsection{Complexity}

By adapting the definition of complexity as "the degree to which an innovation is perceived as difficult to understand and use" [16] to EEMs, this category includes a number of factors as follows: (i) training; (ii) dependency from other components/EEMs; (iii) physical placement inside motor system; (iv) activity type; (v) technical maturity and technology market diffusion and (vi) accessibility.

\subsection{Personnel}

This category refers to the roles impacted by the EEMs adoption and the magnitude in terms of employees involved. The analysis on the roles may provide knowledge regarding the authority and the skills required to successfully adopt an EEM, supporting firms in designing a better strategy [19]. Also, this category may indirectly refer to the ease of implementation, given that the involvement of multiple departments within a firm and personnel with different roles usually implies greater difficulties for the implementation [17]. The factors grouped in the role sub-category differentiate between actively engaged (or required) personnel in the adoption of EEMs from personnel passively undergoing the change (passive). Additionally, despite top management exercise a considerable degree of control, this may be insufficient to transform the firm into a conscious entity with a unitary will [115]. Therefore, the corporate involvement sub-category addresses the extension of the involvement required for any role, i.e., the number of impacted employees, either actively or passively.

\subsection{Additional technical factors}

The category provides further insights into the technical description of EEMs applied to EMS. It includes: (i) implementation type; (ii) check-up frequency; (iii) secondary devices necessary; (iv) additional optimisation devices; and (v) automation.

\section{Table 2}

Novel framework composed of categories, sub-categories and factors to support industrial decision-makers in the assessment of industrial EEMs.

\begin{tabular}{|c|c|c|c|c|c|}
\hline Category & Sub-category & Factors & Description & Phase & References \\
\hline \multirow{4}{*}{ Contextual factors } & & Motor model & $\begin{array}{l}\text { Model of the motors where EEMs will be applied in terms } \\
\text { of efficiency (thus indirectly of age). Among others, it may } \\
\text { provide information regarding compliance with local rules. }\end{array}$ & $\mathrm{I}+\mathrm{S}$ & $\begin{array}{c}{[113,116-} \\
120]\end{array}$ \\
\hline & & Motor size & Motor size (power) for EEMs considerations. & $\mathrm{I}+\mathrm{S}$ & $\begin{array}{l}{[49,113,116,1} \\
20,121]\end{array}$ \\
\hline & & Motors number & Number of motors affected by the EEM. & $\mathrm{I}+\mathrm{S}$ & {$[89,116]$} \\
\hline & & Working hours & $\begin{array}{l}\text { Working hours of the motors where the EEMs will be } \\
\text { applied. It is strongly related to the activity performed by }\end{array}$ & $\mathrm{I}+\mathrm{S}$ & $\begin{array}{c}{[15,116,120,1} \\
22]\end{array}$ \\
\hline
\end{tabular}




\begin{tabular}{|c|c|c|c|c|c|}
\hline Category & Sub-category & Factors & Description & Phase & References \\
\hline & & & the firms and to the role of the motors. & & \\
\hline & & Process focus & $\begin{array}{l}\text { Distinction between process-core and non-process core } \\
\text { activities. Excluding some rare exceptions (see e.g. [88]), it } \\
\text { coincides with the division between production and } \\
\text { ancillary activities. }\end{array}$ & $\mathrm{I}+\mathrm{S}$ & $\begin{array}{l}{[12,13,31,80} \\
91,116]\end{array}$ \\
\hline & & Application load & $\begin{array}{l}\text { Load applied: constant torque load, variable torque load and } \\
\text { constant power load applications. }\end{array}$ & $\mathrm{I}+\mathrm{S}$ & {$[113,120]$} \\
\hline \multirow{4}{*}{ Compatibility } & \multirow[t]{2}{*}{ Load } & Load compatibility & $\begin{array}{l}\text { EEM suitability and compatibility with technologies } \\
\text { embedded in the EEM or existing system. Particularly } \\
\text { important for EMS working in critical conditions (e.g., very } \\
\text { high or low-speed applications, high torque or shock load } \\
\text { applications). }\end{array}$ & $\mathrm{S}$ & {$[98,113]$} \\
\hline & & $\begin{array}{l}\text { Adaptability to different } \\
\text { conditions }\end{array}$ & EEM flexibility in case of changes to the system. & $S$ & l \\
\hline & \multirow[b]{2}{*}{ System } & $\begin{array}{l}\text { Adaptability in every } \\
\text { environment }\end{array}$ & Adequacy of use in the chosen location. & $\mathrm{S}$ & {$[113,123]$} \\
\hline & & Reduced layout flexibility & $\begin{array}{l}\text { The implementation of EEMs could lead to a reduction in } \\
\text { the degree of freedom in designing the configuration of the } \\
\text { plant, because of built-in technological constraints, } \\
\text { especially when layout modifications are not allowed. }\end{array}$ & I & [113] \\
\hline \multirow{7}{*}{\multicolumn{2}{|c|}{ Economy }} & Initial implementation cost & $\begin{array}{l}\text { Implementation costs at "time } 0 \text { " (e.g., equipment } \\
\text { purchases, engineering/contractor fees and adaptation costs). } \\
\text { In the case of technology upgrade, only the marginal costs } \\
\text { should be considered. }\end{array}$ & I & $\begin{array}{c}{[12,13,23,26-} \\
28,98,116]\end{array}$ \\
\hline & & Total adoption cost & $\begin{array}{l}\text { Total investment expenditure throughout the project life } \\
\text { (particularly important in case of repeated implementation). }\end{array}$ & I & l \\
\hline & & $\begin{array}{l}\text { Adoption cost of mandatory } \\
\text { secondary devices }\end{array}$ & $\begin{array}{l}\text { Costs of other secondary devices necessary/mandatory to } \\
\text { fully benefit from the adoption of the EEM. }\end{array}$ & $\mathrm{I}+\mathrm{S}$ & [113] \\
\hline & & $\begin{array}{l}\text { Adoption cost of additional } \\
\text { optimization devices }\end{array}$ & $\begin{array}{l}\text { Costs for additional devices (not mandatory), that could } \\
\text { optimize the benefits of the interventions (e.g., control } \\
\text { devices). }\end{array}$ & $\mathrm{I}+\mathrm{S}$ & [113] \\
\hline & & Financial exposure & $\begin{array}{l}\text { The factor describes whether an EEM could grant a firm } \\
\text { more freedom in managing its finance. }\end{array}$ & $\mathrm{I}+\mathrm{S}$ & l \\
\hline & & Monetary savings & Monetised energy savings. & $\mathrm{S}$ & $\begin{array}{c}{[13,98,120,12} \\
4]\end{array}$ \\
\hline & & Pay-back time & $\begin{array}{l}\text { Pay-back time of the investment, defined as the ratio } \\
\text { between implementation costs and monetised energy } \\
\text { savings. }\end{array}$ & $\mathrm{S}$ & $\begin{array}{l}{[12,13,26,29} \\
30,120,125,1 \\
26]\end{array}$ \\
\hline \multicolumn{3}{|l|}{ Energy savings } & Energy savings in energy units (MJ or kWh). & $\mathrm{S}$ & {$[13,18,35]$} \\
\hline \multirow{9}{*}{$\begin{array}{l}\text { Production-related } \\
\text { factors }\end{array}$} & \multirow{6}{*}{ Global } & Productivity - direct & Direct impacts on the productivity of a firm. & $\mathrm{S}$ & $\begin{array}{l}{[13,19,34,35,} \\
39,40,42,44]\end{array}$ \\
\hline & & Productivity - indirect & $\begin{array}{l}\text { Indirect impacts on the productivity of a firm (e.g., due to } \\
\text { improved working conditions which positively affect the } \\
\text { personnel). }\end{array}$ & $\mathrm{S}$ & [39] \\
\hline & & Production Quality - direct & $\begin{array}{l}\text { Direct variations in production quality (e.g., reductions in } \\
\text { scraps and reworks). }\end{array}$ & $\mathrm{S}$ & $\begin{array}{c}{[23,35,39,42-} \\
44,98]\end{array}$ \\
\hline & & $\begin{array}{l}\text { Production Quality - } \\
\text { indirect }\end{array}$ & Indirect variations in production quality. & $\mathrm{S}$ & l \\
\hline & & Production costs - direct & $\begin{array}{l}\text { Direct variations in production cost (e.g., labour, operations } \\
\text { and maintenance, raw materials, waste or production } \\
\text { disruptions). }\end{array}$ & $\mathrm{S}$ & {$[35,37,39,44]$} \\
\hline & & Production costs - indirect & Indirect variations in production cost. & S & I \\
\hline & \multirow{3}{*}{ Local } & Set-up time & $\begin{array}{l}\text { Variations in the time needed to change configuration when } \\
\text { different operating conditions are required. }\end{array}$ & $\mathrm{S}$ & [113] \\
\hline & & $\begin{array}{l}\text { Reliability of the } \\
\text { equipment }\end{array}$ & $\begin{array}{l}\text { Changes in the reliability of the equipment through the } \\
\text { mean time to failure (MTTF). }\end{array}$ & $S$ & {$[35,39,42,98]$} \\
\hline & & $\begin{array}{l}\text { Downtime for maintenance } \\
\text { and repairs }\end{array}$ & $\begin{array}{l}\text { Changes in the downtime for maintenance and repair } \\
\text { through the mean time to repair (MTTR). Comprehensive of } \\
\text { both the planned and unplanned downtimes. }\end{array}$ & $\mathrm{S}$ & {$[34,35,98]$} \\
\hline
\end{tabular}




\begin{tabular}{|c|c|c|c|c|c|}
\hline Category & Sub-category & Factors & Description & Phase & References \\
\hline & & $\begin{array}{l}\text { Downtime for } \\
\text { implementation }\end{array}$ & $\begin{array}{l}\text { Time interval including the installation, testing and the start- } \\
\text { up of the new equipment as well as the decommissioning of } \\
\text { the existing equipment (in case of substitution). When } \\
\text { dealing with a practice, it can be considered as the time to } \\
\text { effectively implement it. }\end{array}$ & I & {$[34,36]$} \\
\hline & & Equipment lifetime & $\begin{array}{l}\text { Variations in the equipment lifetime as a consequence of } \\
\text { EEMs adoption. It may be affected by the different } \\
\text { conditions of wear and tear to which the equipment is } \\
\text { subjected. }\end{array}$ & $S$ & $\begin{array}{l}{[12,34,35,39,} \\
98]\end{array}$ \\
\hline & & Process control & Variations in the level of process control. & S & [38] \\
\hline \multirow{11}{*}{$\begin{array}{l}\text { Operations-related } \\
\text { factors }\end{array}$} & \multirow{4}{*}{$\begin{array}{l}\text { Motor } \\
\text { conditions }\end{array}$} & Equipment temperature & $\begin{array}{l}\text { Variations in the equipment temperature (cooling } \\
\text { requirements). }\end{array}$ & S & {$[8,39,98]$} \\
\hline & & Equipment vibrations & $\begin{array}{l}\text { Variations in the vibrations to which the equipment is } \\
\text { subjected. }\end{array}$ & $\mathrm{S}$ & {$[59,76,89,98]$} \\
\hline & & Equipment power quality & $\begin{array}{l}\text { Variations in power quality (e.g., power factor, voltage } \\
\text { unbalance, off-design voltages and harmonic distortion). }\end{array}$ & S & {$[98,113]$} \\
\hline & & Equipment air quality & $\begin{array}{l}\text { Variations in the air quality that reaches the physical } \\
\text { devices. }\end{array}$ & S & [113] \\
\hline & \multirow{5}{*}{$\begin{array}{l}\text { Working } \\
\text { environment }\end{array}$} & Noise & Variations in the noise within the working environment. & $\mathrm{S}$ & $\begin{array}{c}34,35,38,39, \\
42,58]\end{array}$ \\
\hline & & Environmental temperature & Variations in the temperature of the working environment. & S & [39] \\
\hline & & Environmental vibrations & $\begin{array}{l}\text { Variations in the vibrations perceived by operators within } \\
\text { the working environment. }\end{array}$ & S & I \\
\hline & & Health and Safety & $\begin{array}{l}\text { Variations in the health and safety conditions for the } \\
\text { operators within the working environment, including the } \\
\text { avoided need for personal protective equipment. }\end{array}$ & S & $\begin{array}{l}{[34,35,38,42,} \\
58]\end{array}$ \\
\hline & & Air quality & $\begin{array}{l}\text { Variations in the air quality of the working environment } \\
\text { after the adoption of EEMs. }\end{array}$ & $\mathrm{S}$ & {$[34,38,39,42]$} \\
\hline & \multirow{2}{*}{$\begin{array}{l}\text { External } \\
\text { environment }\end{array}$} & Waste & Variations in the amount of waste generated. & S & $\begin{array}{l}{[13,20,34,35,} \\
38-40,42,62]\end{array}$ \\
\hline & & Emissions & $\begin{array}{l}\text { Variations in the amount of GHG and dust emissions. It may } \\
\text { affect firm compliance with local regulations. }\end{array}$ & S & $\begin{array}{l}{[13,34,35,39,} \\
42,44,63,127, \\
128]\end{array}$ \\
\hline \multicolumn{3}{|l|}{ Synergies } & $\begin{array}{l}\text { Synergies between different EEMs which could be exploited } \\
\text { to gain advantages. }\end{array}$ & $\mathrm{I}+\mathrm{S}$ & [36] \\
\hline \multirow{6}{*}{\multicolumn{2}{|c|}{ Complexity }} & Training & Level of training required to adopt an EEM. & $\mathrm{I}+\mathrm{S}$ & $\begin{array}{c}22- \\
24,72,125,12 \\
9] \\
\end{array}$ \\
\hline & & $\begin{array}{l}\text { Dependency from other } \\
\text { components/EEMs }\end{array}$ & $\begin{array}{l}\text { Magnitude of influence of an EEM, distinguishing between } \\
\text { interventions impacting the specific devices, sub-systems or } \\
\text { the wider surrounding system. }\end{array}$ & $S$ & {$[12,17]$} \\
\hline & & $\begin{array}{l}\text { Physical placement inside } \\
\text { motor system }\end{array}$ & $\begin{array}{l}\text { EMS area addressed by the EEM (location of installation for } \\
\text { physical devices or targeted area for procedures). The } \\
\text { intervention may be related to a single component of the } \\
\text { motor system or the connection between systems } \\
\text { (component wide variation) or the entire motor system } \\
\text { (architectural innovation). The installation of a new } \\
\text { component could also lead to an architectural innovation by } \\
\text { shifting the importance of other components in the system. }\end{array}$ & I & {$[20,32]$} \\
\hline & & Activity type & $\begin{array}{l}\text { Nature of an EEM, distinguishing between a procedure, a } \\
\text { new equipment installation, an optimization in the use of } \\
\text { existing technology or an equipment retrofitting. }\end{array}$ & I & $\begin{array}{l}{[12,13,19,68,} \\
130]\end{array}$ \\
\hline & & $\begin{array}{l}\text { Technical maturity and } \\
\text { diffusion of the technology } \\
\text { in the market }\end{array}$ & $\begin{array}{l}\text { Technical maturity of an EEM and its level of diffusion in } \\
\text { the market. }\end{array}$ & I & $\begin{array}{l}{[12,72,131-} \\
133]\end{array}$ \\
\hline & & Accessibility & Difficulty to access the location where the EMS is installed. & $\mathrm{I}+\mathrm{S}$ & [75] \\
\hline \multirow{3}{*}{ Personnel } & \multirow{2}{*}{ Role } & Active personnel & Personnel actively engaged during the adoption. & $\mathrm{I}+\mathrm{S}$ & {$[8,12,19]$} \\
\hline & & Passive personnel & Personnel who passively undergoes the adoption. & $\mathrm{I}+\mathrm{S}$ & I \\
\hline & $\begin{array}{l}\text { Corporate } \\
\text { involvement }\end{array}$ & $\begin{array}{l}\text { Active corporate } \\
\text { involvement }\end{array}$ & Extent of involvement by personnel actively engaged. & I & {$[13]$} \\
\hline
\end{tabular}




\begin{tabular}{|c|c|c|c|c|c|}
\hline \multirow[t]{2}{*}{ Category } & Sub-category & Factors & Description & \multirow{2}{*}{$\begin{array}{c}\text { Phase } \\
\text { I }\end{array}$} & \multirow{2}{*}{$\begin{array}{c}\text { References } \\
{[13]}\end{array}$} \\
\hline & & $\begin{array}{l}\text { Passive corporate } \\
\text { involvement }\end{array}$ & $\begin{array}{l}\text { Extent of involvement by personnel who passively } \\
\text { undergoes the adoption. }\end{array}$ & & \\
\hline \multirow{5}{*}{\multicolumn{2}{|c|}{ Additional technical factors }} & Implementation type & $\begin{array}{l}\text { Single-step or multiple times installation, thus providing } \\
\text { information about how the effort is distributed along the } \\
\text { lifetime of the measure. }\end{array}$ & I & I \\
\hline & & Check-up frequency & One-time effort or periodic check. & $\mathrm{S}$ & {$[13,134]$} \\
\hline & & $\begin{array}{l}\begin{array}{l}\text { Secondary devices } \\
\text { necessary }\end{array} \\
\end{array}$ & $\begin{array}{l}\text { Technical needs of mandatory secondary devices to benefits } \\
\text { from EEMs adoption. }\end{array}$ & $\mathrm{I}+\mathrm{S}$ & I \\
\hline & & $\begin{array}{l}\text { Additional optimization } \\
\text { devices }\end{array}$ & $\begin{array}{l}\text { Technical needs of suggested secondary devices to benefits } \\
\text { from EEMs adoption. }\end{array}$ & $\mathrm{I}+\mathrm{S}$ & I \\
\hline & & Automation & Eligibility of EEM for automation. & $\mathrm{S}$ & 1 \\
\hline
\end{tabular}

\section{Research methods}

The theoretical framework has been tested in the field with industrial decision-makers to verify its completeness and its applicability as an assessment tool, capable of pointing out the major factors driving the adoption of EEMs in EMS. The multiple case study methodology has been adopted following a replication logic, choosing independent cases to obtain similar results, in line with Yin [135] and Voss et al. [136]. Indeed, the differences in the businesses and the environment could deeply influence the perception of factors and categories and, in turn, the approach toward the adoption of EEMs. The selected sample encompasses Italian firms within different sectors, firm size and energy use, thus potentially characterized by different behaviours toward the adoption of EEMs. Indeed, larger firms are usually more structured compared to smaller ones, with a more structured decision-making chain [137]. Moreover, the choice of the sector could lead to different applications of EMS, thus also influencing the adoption rate of EEMs, beyond a different relevance of energy costs and savings. Finally, the six sampled firms (details in Table 3) are located in two large manufacturing regions contributing to about $30 \%$ of the Italian GDP [138].

\section{Table 3}

Sample of companies and EEMs selected for the validation of the framework.

\begin{tabular}{|c|c|c|c|c|c|c|c|c|c|}
\hline Firm & Sector & $\begin{array}{c}\text { Size } \\
\text { [employees] }\end{array}$ & $\begin{array}{c}\text { Turnover } \\
{[\mathrm{M} €]}\end{array}$ & $\begin{array}{c}\text { Energy } \\
\text { intensity } \\
{\left[\text { EI/NEI] }{ }^{1}\right.}\end{array}$ & $\begin{array}{l}\text { Role of the } \\
\text { Intervie wee }\end{array}$ & EEMs & EMS targeted & EEM type & $\begin{array}{l}\text { EEM } \\
\text { code }\end{array}$ \\
\hline \multirow{2}{*}{1} & \multirow{2}{*}{$\begin{array}{l}\text { Boiler } \\
\text { construction } \\
\text { and } \\
\text { carpentry }\end{array}$} & \multirow{2}{*}{$101 \div 150$} & \multirow{2}{*}{27} & \multirow{2}{*}{ NEI } & \multirow{2}{*}{$\begin{array}{c}\text { Plant } \\
\text { manager }\end{array}$} & $\begin{array}{l}\text { Use adjustable frequency } \\
\text { drive to replace throttling } \\
\text { system (ARC } 2,4143 \text { ) }\end{array}$ & $\begin{array}{l}3 \mathrm{KW} \text { motor used } \\
\text { for equipment } \\
\text { testing }\end{array}$ & Implemented & $\begin{array}{c}\text { EEM } \\
1-1\end{array}$ \\
\hline & & & & & & $\begin{array}{l}\text { Use most efficient types } \\
\text { of electric motors (ARC } \\
2,4133 \text { ) }\end{array}$ & $\begin{array}{c}3 \times 1,5 \mathrm{KW} \text { motors } \\
\text { used for } \\
\text { ventilation fans }\end{array}$ & Implemented & $\begin{array}{c}\text { EEM } \\
1-2\end{array}$ \\
\hline \multirow[b]{2}{*}{2} & \multirow{2}{*}{$\begin{array}{c}\text { Food \& } \\
\text { beverage }\end{array}$} & \multirow[b]{2}{*}{$10 \div 50$} & \multirow[b]{2}{*}{19} & \multirow[b]{2}{*}{ NEI } & \multirow{2}{*}{$\begin{array}{l}\text { Maintenance } \\
\text { responsible }\end{array}$} & Use VSDs & $\begin{array}{l}1,5 \mathrm{KW} \text { motor } \\
\text { used for wine } \\
\text { racking }\end{array}$ & $\begin{array}{c}\text { Not } \\
\text { implemented }\end{array}$ & $\begin{array}{c}\text { EEM } \\
2-1\end{array}$ \\
\hline & & & & & & $\begin{array}{l}\text { Utilize energy-efficient } \\
\text { belts and other improved } \\
\text { mechanisms (ARC } \\
2,4111 \text { ) }\end{array}$ & $\begin{array}{l}7 \text { motors with a } \\
\text { power up to } 8 \\
\text { KW used for } \\
\text { material handling }\end{array}$ & Implemented & $\begin{array}{c}\text { EEM } \\
2-2\end{array}$ \\
\hline
\end{tabular}




\begin{tabular}{|c|c|c|c|c|c|c|c|c|c|}
\hline Firm & Sector & $\begin{array}{c}\text { Size } \\
\text { [employees] }\end{array}$ & $\begin{array}{c}\text { Turnover } \\
{[\mathrm{M} €]}\end{array}$ & $\begin{array}{c}\text { Energy } \\
\text { intensity } \\
{[\mathrm{EI} / \mathrm{NEI}]^{1}}\end{array}$ & $\begin{array}{l}\text { Role of the } \\
\text { Inte rvie wee }\end{array}$ & EEMs & EMS targeted & EEM type & $\begin{array}{c}\text { EEM } \\
\text { code }\end{array}$ \\
\hline \multirow{3}{*}{3} & \multirow{3}{*}{$\begin{array}{c}\text { Plastic \& } \\
\text { packaging }\end{array}$} & \multirow{3}{*}{$151 \div 249$} & \multirow{3}{*}{90} & \multirow{3}{*}{ EI } & \multirow{3}{*}{$\begin{array}{l}\text { Deputy } \\
\text { Maintenance } \\
\text { responsible }\end{array}$} & $\begin{array}{l}\text { Utilize energy-efficient } \\
\text { belts and other improved } \\
\text { mechanisms (ARC } \\
2,4111 \text { ) }\end{array}$ & $\begin{array}{l}7 \times 50 \mathrm{KW} \text { motors } \\
\text { used for a cutting } \\
\text { press }\end{array}$ & $\begin{array}{c}\text { Not } \\
\text { implemented }\end{array}$ & $\begin{array}{c}\text { EEM } \\
3-1\end{array}$ \\
\hline & & & & & & $\begin{array}{l}\text { Replace DC equipment } \\
\text { with AC equipment (ARC } \\
2,3311 \text { ) }\end{array}$ & $\begin{array}{l}\text { 30x3 KW motors } \\
\text { used for material } \\
\text { handling }\end{array}$ & Implemented & $\begin{array}{c}\text { EEM } \\
3-2\end{array}$ \\
\hline & & & & & & Use VSDs & $\begin{array}{l}140 \mathrm{KW} \text { motor } \\
\text { used in a screw } \\
\text { extruder }\end{array}$ & Implemented & $\begin{array}{c}\text { EEM } \\
3-3\end{array}$ \\
\hline \multirow{2}{*}{4} & \multirow{2}{*}{$\begin{array}{c}\text { Steel } \\
\text { rolling }\end{array}$} & \multirow{2}{*}{$51 \div 100^{2}$} & \multirow{2}{*}{90} & \multirow{2}{*}{ EI } & \multirow{2}{*}{$\begin{array}{l}\text { Maintenance } \\
\text { responsible }\end{array}$} & $\begin{array}{l}\text { Establish a preventive } \\
\text { maintenance program } \\
(\text { ARC } 2,4156)\end{array}$ & $\begin{array}{l}900 \mathrm{KW} \text { motor } \\
\text { used for material } \\
\text { handling }\end{array}$ & Implemented & $\begin{array}{c}\text { EEM } \\
4-1\end{array}$ \\
\hline & & & & & & $\begin{array}{l}\text { Replace DC equipment } \\
\text { with AC equipment (ARC } \\
2,3311 \text { ) }\end{array}$ & $\begin{array}{c}6 \times 150 \mathrm{KW} \\
\text { motors used for } \\
\text { steel lamination }\end{array}$ & $\begin{array}{c}\text { Not } \\
\text { implemented }\end{array}$ & $\begin{array}{c}\text { EEM } \\
4-2\end{array}$ \\
\hline \multirow{2}{*}{5} & \multirow{2}{*}{$\begin{array}{l}\text { Machine } \\
\text { assembly }\end{array}$} & \multirow{2}{*}{$51 \div 100$} & \multirow{2}{*}{12} & \multirow{2}{*}{ NEI } & \multirow{2}{*}{$\begin{array}{l}\text { CEO and } \\
\text { owner }\end{array}$} & $\begin{array}{l}\text { Use most efficient types } \\
\text { of electric motors (ARC } \\
2,4133 \text { ) }\end{array}$ & $\begin{array}{l}3,5 \mathrm{KW} \text { motor } \\
\text { used for material } \\
\text { handling }\end{array}$ & $\begin{array}{c}\text { Not } \\
\text { implemented }\end{array}$ & $\begin{array}{c}\text { EEM } \\
5-1\end{array}$ \\
\hline & & & & & & $\begin{array}{l}\text { Upgrade control on } \\
\text { compressors (ARC } \\
2,4224)\end{array}$ & $\begin{array}{l}17 \mathrm{KW} \text { motor } \\
\text { used for HVAC }\end{array}$ & Implemented & $\begin{array}{c}\text { EEM } \\
5-2\end{array}$ \\
\hline 6 & Iron \& steel & $\geq 250^{3}$ & 1 & EI & $\begin{array}{c}\text { Electrical } \\
\text { maintenance } \\
\text { responsible }\end{array}$ & $\begin{array}{l}\text { Install isolation } \\
\text { transformers }\end{array}$ & $\begin{array}{l}3 \text { motors with a } \\
\text { power up to } 3,5 \\
\text { MW used for } \\
\text { steel lamination }\end{array}$ & Implemented & $\begin{array}{c}\text { EEM } \\
6-1\end{array}$ \\
\hline
\end{tabular}

${ }^{1}$ Firms are labelled as energy-intensive when their energy costs exceed $2 \%$ of the total annual turnover [11].

${ }^{2}$ The plant interviewed belongs to a larger corporate employing about 1100 people.

${ }^{3}$ The plant belongs to a larger corporate employing about 6500 people with total revenue of $€ 5$ billion.

In-field interviews are carried out following the semi-structured approach [139], to allow the partial customization required by the heterogeneity of situations under analysis.

Each interview has started with a brief description of the firm and its main production processes. The discussion has also explored the relevance and the characteristics of EMS and the required applications. The decisionmaking process is then investigated, together with the role of the respondents for the adoption of EEMs in EMS, followed by a brief overview of the EEMs implemented in the past.

The second part of the interview has dealt with the preliminary validation of the framework according to a predetermined set of indicators. A Likert scale from one (poor) to four (excellent) is used, similarly to [75]. The features interested by the analysis firstly has encompassed the structure, scope and perspective of the framework, followed by the categories, sub-categories and factors, considered in this step as clusters. After the understanding by the responding of the overarching framework structure, the analysis has moved into the details of the single categories, sub-categories and factors. Table 4 shows the indicators used and their specific role in the validation of each element of the framework.

\section{Table 4}

Indicators for the validation of the framework completeness, classification, usefulness and clearness. 


\begin{tabular}{|c|c|c|c|c|}
\hline Framework & Completeness & Classification & Usefulness & Clearness \\
\hline & & & & $\mathrm{X}$ \\
\hline & & & $\mathrm{X}$ & $\mathrm{X}$ \\
\hline & & & & $\mathrm{X}$ \\
\hline Categories & $\mathrm{X}$ (cluster) & & $\bar{X}$ & $\mathrm{X}$ \\
\hline Sub-categories & $\mathrm{X}$ (cluster) & & $\bar{X}$ & $\mathrm{X}$ \\
\hline Factors & $\mathrm{X}$ (cluster) & $\mathrm{X}$ (cluster) & $\mathrm{X}$ & $\mathrm{X}$ \\
\hline
\end{tabular}

Upon completion of the preliminary validation, the framework has been further validated in terms of completeness and usefulness through the investigation of twelve heterogeneous EEMs selected from [113] among the most implemented in industry [9] (Table 3). The sample includes both EEMs which were successfully adopted by the firms and still in place (implemented EEMs), those considered for adoption but not implemented or adopted but then removed (not implemented EEMs). Respondents are required to point out which factors were considered and deemed important in order to adopt EMS EEMs. Moreover, in the final phase of the empirical validation, they are asked whether a different decision would have been taken if the framework had been available to support them. The flow chart of the methodology process is described in Fig. 1.

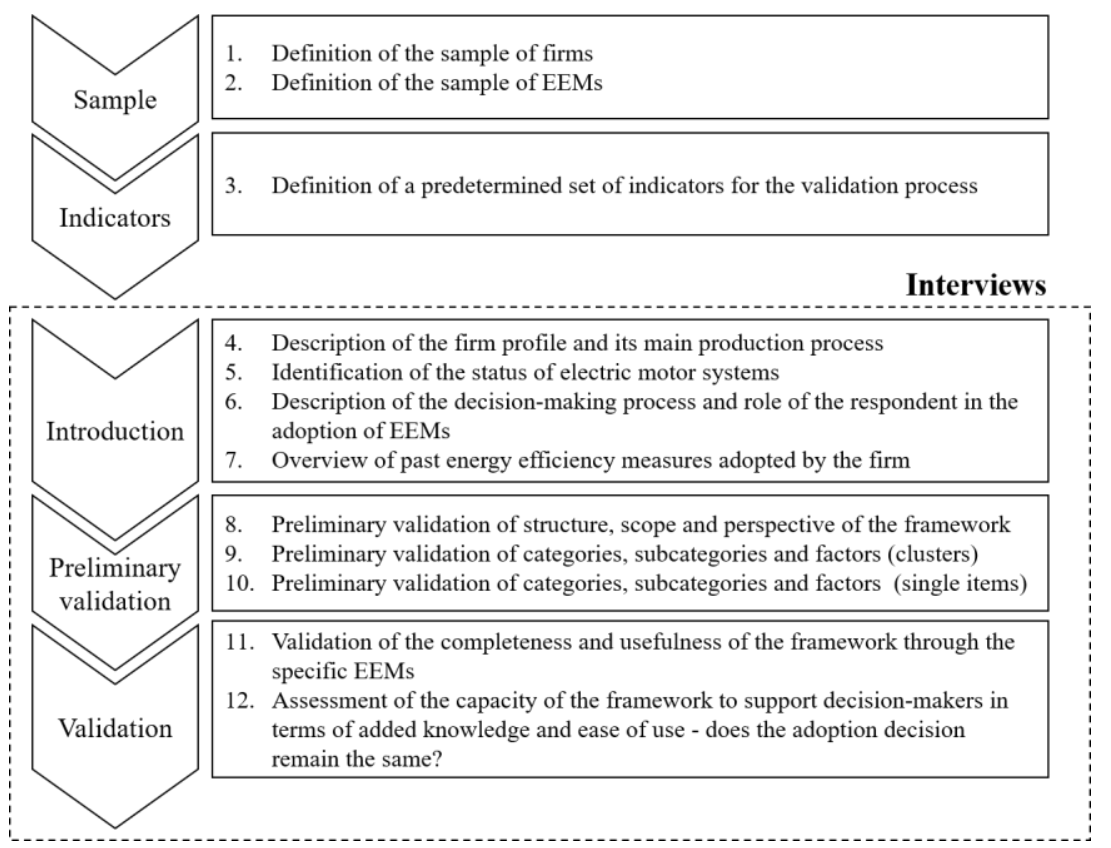

Fig. 1. Flow chart of the methodology process.

\section{Results}

The preliminary validation has allowed gathering some valuable insights for the framework, with interviewees positively judging all indicators (details reported in Table A1 in the Appendix). In particular, interviewees noted that all the factors potentially affecting the adoption of EEMs in EMS have been included. Further, there were no major concerns regarding the classification into categories and sub-categories. In this regard, the structure has been acknowledged and deemed appropriate, and factors well understood by decision-makers. Finally, the overall evaluation of the usefulness resulted extremely positive. 
Regarding the second phase of the validation, Table 5 and Table 6 present the empirical results based on two specific EEMs, EEM 2-1 and EEM 3.2 respectively, followed by more general comments over the general validation.

\section{Table 5}

Validation of the framework through EEM 2-1, pointing out: factors considered useful $(\checkmark)$ in the EEMs assessment; factors assessed and eventually driving the adoption decision, both positive (EEM implemented, $\checkmark \checkmark$ ) and negative (EEM not implemented, $\checkmark \checkmark *$ ); factors neglected from the EEMs assessment, both negligible $(\mathrm{O})$, important $(\mathrm{X})$ and potentially reversing the decision $(\mathrm{X} X)$ with respect to the outcome.

\begin{tabular}{|c|c|c|c|c|}
\hline \multicolumn{5}{|c|}{ Validation of the frame work: EEM 2-1 } \\
\hline \multicolumn{4}{|l|}{ Firm profile } & - Small non-energy intensive firm belonging to the food\&beverage sector. \\
\hline \multicolumn{4}{|l|}{ Production } & $\begin{array}{l}\text { - The firm produces wine and the process includes all the phases from the } \\
\text { pressing of harvested grapes to the bottling of the final products. }\end{array}$ \\
\hline \multicolumn{4}{|l|}{ EMS } & $\begin{array}{l}\text { - More than } 200 \text { motors, some of them running continuously } 24 \text { hours per } \\
\text { day. The maximum power is } 10 \mathrm{KW} \text {. }\end{array}$ \\
\hline \multicolumn{4}{|c|}{ Decision-making } & $\begin{array}{l}\text { - Given the low share of energy cost, about } 0,8 \% \text { of the total turnover, an } \\
\text { energy manager is missing. The EEMs are carried out by the respondent } \\
\text { (maintenance responsible), supported by external service providers for the } \\
\text { most expertise requiring EEMs. }\end{array}$ \\
\hline \multicolumn{4}{|l|}{ EEM } & $\begin{array}{l}\text { - Installation of a VSD coupled with a pump actioned by a } 1.5 \mathrm{KW} \text { motor } \\
\text { and used for wine racking from one pool to another (EEM 2-1). }\end{array}$ \\
\hline \multicolumn{4}{|l|}{ EEM type } & - Not implemented (implemented but soon removed). \\
\hline \multicolumn{4}{|c|}{ Frame work } & Factors consideration and notes for firm 2 \\
\hline \multirow{6}{*}{\multicolumn{2}{|c|}{$\begin{array}{l}\text { Descriptive } \\
\text { factors }\end{array}$}} & Motor model & $\checkmark$ & \multirow{6}{*}{ - Considered in the analysis as the basis of the assessment } \\
\hline & & Motor size & $\checkmark$ & \\
\hline & & Motors numerosity & $\checkmark$ & \\
\hline & & \begin{tabular}{|l|} 
Working hours \\
\end{tabular} & $\checkmark$ & \\
\hline & & Process focus & $\checkmark$ & \\
\hline & & Application load & $\checkmark$ & \\
\hline \multirow{4}{*}{ Compatibility } & \multirow[t]{2}{*}{ Load } & Load compatibility & X X & \multirow{2}{*}{$\begin{array}{l}\text { - The analysis of the load compatibility was limited to the initial } \\
\text { configuration, which unfortunately represented the best scenario with respect } \\
\text { to all the different phases of the racking process. To perform a complete } \\
\text { racking of wine, the process is stopped multiple time according to the level } \\
\text { reached by the wine in the pool. However, with the progressive movement of } \\
\text { wine from one pool to another, the static head acting on the pump inc reased } \\
\text { to unbearable levels for the VSD, which was soon removed from the process. }\end{array}$} \\
\hline & & Adaptability to different conditions & $\checkmark$ & \\
\hline & \multirow{2}{*}{ System } & Adaptability in every environment & $\checkmark$ & \multirow{2}{*}{$\begin{array}{l}\text { - The compatibility of the EEM with the system was considered and no } \\
\text { issues were detected. }\end{array}$} \\
\hline & & Reduced layout flexibility & $\checkmark$ & \\
\hline \multirow{7}{*}{\multicolumn{2}{|c|}{ Economy }} & Initial implementation cost & $\checkmark \checkmark$ & \multirow{7}{*}{$\begin{array}{l}\text { - Cost represented a major barrier to the adoption, but the analysis of the } \\
\text { benefits led to an acceptable pay-back time. } \\
\text { - They were not aware of the potential need to invest in additional devices to } \\
\text { improve the power quality against the harmonic distortion introduced by the } \\
\text { VSD. }\end{array}$} \\
\hline & & Total adoption cost & $\checkmark \checkmark$ & \\
\hline & & Adoption cost of secondary devices & $\mathrm{X}$ & \\
\hline & & $\begin{array}{l}\text { Adoption cost of additional } \\
\text { optimization de vices }\end{array}$ & $\mathrm{O}$ & \\
\hline & & Financial exposure & O & \\
\hline & & Monetary savings & $\checkmark$ & \\
\hline & & Pay-back time & $\checkmark \checkmark$ & \\
\hline \multicolumn{3}{|l|}{ Energy benefits } & $\checkmark$ & - Low energy savings due to the reduced consumption of the motor. \\
\hline \multirow{12}{*}{$\begin{array}{l}\text { Production } \\
\text { related factors }\end{array}$} & \multirow{6}{*}{ Global } & Productivity - direct & $\checkmark \checkmark$ & \multirow{6}{*}{$\begin{array}{l}\text { - Productivity improvement is one of the main reasons driving the adoption } \\
\text { of the EEM. } \\
\text { - The indirect impacts on productivity were not considered, but their impact } \\
\text { would have been negligible since just one small motor was affected by the } \\
\text { EEM. }\end{array}$} \\
\hline & & Productivity - indirect & O & \\
\hline & & Production quality - direct & $\checkmark$ & \\
\hline & & Production quality - indirect & $\mathrm{O}$ & \\
\hline & & Production cost - direct & $\checkmark$ & \\
\hline & & Production cost - indirect & 0 & \\
\hline & \multirow{6}{*}{ Local } & Set-up time & $\checkmark$ & \multirow{6}{*}{$\begin{array}{l}\text { - The improvement in process control was the main reasons driving the } \\
\text { adoption of the EEM. }\end{array}$} \\
\hline & & Reliability & $\checkmark$ & \\
\hline & & Downtime for maintenance and repair & $\checkmark$ & \\
\hline & & Downtime for implementation & $\checkmark$ & \\
\hline & & Equipment lifetime & $\checkmark$ & \\
\hline & & Improved process control & $\checkmark \checkmark$ & \\
\hline \multirow{3}{*}{$\begin{array}{l}\text { Operations } \\
\text { related factors }\end{array}$} & \multirow{3}{*}{$\begin{array}{l}\text { Motor } \\
\text { conditions }\end{array}$} & Equipment temperature & $\checkmark$ & \multirow{3}{*}{$\begin{array}{l}\text { - Motor conditions were considered but reported only slight variations due to } \\
\text { the reduction of speed during the great majority of the operating time. }\end{array}$} \\
\hline & & \begin{tabular}{|l|} 
Equipment vibrations \\
\end{tabular} & $\checkmark$ & \\
\hline & & Equipment power quality & $\checkmark$ & \\
\hline
\end{tabular}




\begin{tabular}{|c|c|c|c|c|}
\hline \multicolumn{5}{|c|}{ Validation of the frame work: EEM 2-1 } \\
\hline & & Equipment air quality & $\checkmark$ & \\
\hline & \multirow{5}{*}{$\begin{array}{l}\text { Working } \\
\text { environment }\end{array}$} & Air quality & $\checkmark$ & \multirow{5}{*}{$\begin{array}{l}\text { - The conditions of the working environment were considered but did not } \\
\text { change due to the single small motor impacted by the EEM, which was } \\
\text { moreover placed away from the working area. }\end{array}$} \\
\hline & & Noise & $\checkmark$ & \\
\hline & & Environmental temperature & $\checkmark$ & \\
\hline & & Environmental vibrations & $\checkmark$ & \\
\hline & & Health and safety & $\checkmark$ & \\
\hline & \multirow{2}{*}{$\begin{array}{l}\text { External } \\
\text { environment }\end{array}$} & Waste & O & \multirow{2}{*}{$\begin{array}{l}\text { - Variations in the external environment were not considered. They would } \\
\text { have not impacted the adoption. }\end{array}$} \\
\hline & & Emission & $\mathrm{O}$ & \\
\hline \multicolumn{3}{|l|}{ Synergies } & $\mathrm{O}$ & $\begin{array}{l}\text { - Synergies were not known by the decision-maker, but even if considered } \\
\text { they would have not impacted the adoption. }\end{array}$ \\
\hline \multirow{6}{*}{\multicolumn{2}{|c|}{ Complexity }} & Training & $\checkmark$ & \multirow{6}{*}{$\begin{array}{l}\text { - Complexity factors were considered, especially regarding the required } \\
\text { training to maintain the VSD and the reduced level of risk introduced by the } \\
\text { activity type. }\end{array}$} \\
\hline & & $\begin{array}{l}\text { Dependency from other components/ } \\
\text { EEMs }\end{array}$ & $\checkmark$ & \\
\hline & & $\begin{array}{l}\text { Physical placement inside motor } \\
\text { system }\end{array}$ & $\checkmark$ & \\
\hline & & Activity type & $\checkmark$ & \\
\hline & & $\begin{array}{l}\text { Technical maturity and diffusion of } \\
\text { the technology in the market }\end{array}$ & $\checkmark$ & \\
\hline & & Accessibility & $\checkmark$ & \\
\hline \multirow{4}{*}{ Personnel } & Role & Active personnel & $\checkmark$ & \multirow{2}{*}{$\begin{array}{l}\text { - No great variations impacted the personnel beside the additional training, } \\
\text { however limited to the maintenance personnel. }\end{array}$} \\
\hline & Kole & Passive personnel & $\checkmark$ & \\
\hline & \multirow{2}{*}{$\begin{array}{l}\text { Corporate } \\
\text { involvement }\end{array}$} & Active corporate involvement & $\checkmark$ & \multirow{2}{*}{$\begin{array}{l}\text { - Only the involvement of the respondent was required to carry out the } \\
\text { adoption. }\end{array}$} \\
\hline & & Passive corporate involvement & $\checkmark$ & \\
\hline \multirow{5}{*}{\multicolumn{2}{|c|}{ Additional technical factors }} & Implementation type & $\checkmark$ & \multirow{5}{*}{$\begin{array}{l}\text { - They were not aware of the potential need to install additional devices to } \\
\text { cope with the power quality issues generated by the VSD. }\end{array}$} \\
\hline & & Check-up frequency & $\checkmark$ & \\
\hline & & Secondary devices necessary & $\mathrm{X}$ & \\
\hline & & Additional optimization devices & $\mathrm{X}$ & \\
\hline & & Automation & $\checkmark$ & \\
\hline
\end{tabular}

\section{Table 6}

Validation of the framework through EEM 3-2, pointing out: factors considered useful $(\checkmark)$ in the EEMs assessment; factors assessed and eventually driving the adoption decision, both positive (EEM implemented, $\checkmark \checkmark$ ) and negative (EEM not implemented, $\checkmark \checkmark^{*}$ ); factors neglected from the EEMs assessment, both negligible $(\mathrm{O})$, important $(\mathrm{X})$ and potentially reversing the decision $(\mathrm{X} \mathrm{X})$ with respect to the outcome.

\begin{tabular}{|c|c|c|c|c|}
\hline \multicolumn{5}{|c|}{ Validation of the frame work: EEM 3-2 } \\
\hline \multicolumn{4}{|l|}{ Firm profile } & - Medium energy-intensive firm belonging to the plastic\&packaging sector. \\
\hline \multicolumn{4}{|l|}{ Production } & $\begin{array}{l}\text { - The firm realizes plastic products such as containers or disposable } \\
\text { tableware used in the food sector. } \\
\text { - } 20 \text { lines are installed to carry out the production, each of them divided into } \\
\text { two sections: the first is responsible for the creation of plastic sheets from } \\
\text { raw powder, while in the second the sheets are heated up, vacuum-formed in } \\
\text { a mould and eventually cut through a press. }\end{array}$ \\
\hline \multicolumn{4}{|l|}{ EMS } & $\begin{array}{l}- \text { The total power installed is about } 5 \mathrm{MW} \text {, with motors ranging in size up to } \\
140 \mathrm{KW} \text {. }\end{array}$ \\
\hline \multicolumn{4}{|c|}{ Decision-making } & $\begin{array}{l}\text { - Despite the high share of energy costs, about } 4 \% \text { of the total turnover, an } \\
\text { energy manager is missing, hence EEMs are implemented by the respondent } \\
\text { (deputy maintenance responsible) together with the maintenance responsible. }\end{array}$ \\
\hline \multicolumn{4}{|l|}{ EEM } & $\begin{array}{l}\text { - Replacement of } 30 \text { old } 3 \mathrm{KW} \text { DC motors powering the material handling } \\
\text { system of two production lines with the corresponding AC devices (EEM } 3 \text { - } \\
\text { 2). }\end{array}$ \\
\hline \multicolumn{4}{|l|}{ EEM type } & - Implemented. \\
\hline \multicolumn{4}{|c|}{ Frame work } & Factors consideration and notes for firm 3 \\
\hline \multirow{6}{*}{\multicolumn{2}{|c|}{$\begin{array}{l}\text { Descriptive } \\
\text { factors }\end{array}$}} & Motor model & $\checkmark$ & \multirow{6}{*}{ - Considered in the analysis as the basis of the assessment } \\
\hline & & Motor size & $\checkmark$ & \\
\hline & & Motors numerosity & $\checkmark$ & \\
\hline & & Working hours & $\checkmark$ & \\
\hline & & Process focus & $\checkmark$ & \\
\hline & & Application load & $\checkmark$ & \\
\hline \multirow[t]{2}{*}{ Compatibility } & \multirow[t]{2}{*}{ Load } & Load compatibility & $\checkmark$ & \multirow{2}{*}{$\begin{array}{l}\text { - Despite AC devices are usually characterized by a lower torque with } \\
\text { respect to their DC counterparts, the analysis of the load compatibility did } \\
\text { not highlight problems due to the limited requirements from the load. } \\
\text { - To be compatible with the speed modularity required by the material } \\
\text { handling system (i.e., compatibility to different conditions), the firm was } \\
\text { forced to couple the new devices with VSDs. }\end{array}$} \\
\hline & & Adaptability to different conditions & $\checkmark \checkmark$ & \\
\hline
\end{tabular}




\begin{tabular}{|c|c|c|c|c|}
\hline \multicolumn{5}{|c|}{ Validation of the frame work: EEM 3-2 } \\
\hline & & & & $\begin{array}{l}\text { - With this EEM the firm moved toward the standardization of the } \\
\text { equipment, with the aim of increasing the compatibility of the devices in } \\
\text { terms of adaptability to different conditions. }\end{array}$ \\
\hline & \multirow{2}{*}{ System } & Adaptability in every environment & $\mathrm{O}$ & \multirow{2}{*}{$\begin{array}{l}\text { - The adaptability of the devices in the environment was not considered, but } \\
\text { no problems would arise because of the strict environmental standards the } \\
\text { firm is subjected to due to the collaboration with the food sector. } \\
\text { - The limited layout flexibility of a rigid system such as a production line } \\
\text { could have been a problem with the installation of VSD, which must be } \\
\text { placed not too far from the control centre. However, no problems arose. }\end{array}$} \\
\hline & & Reduced layout flexibility & $\checkmark$ & \\
\hline \multirow{7}{*}{\multicolumn{2}{|c|}{ Economy }} & Initial implementation cost & $\checkmark \checkmark$ & \multirow{7}{*}{$\begin{array}{l}\text { - The adoption of new AC devices consistently reduced the high costs in } \\
\text { which the firm was incurring to find spare parts for the old DC devices, no } \\
\text { longer widely diffused in the market. } \\
\text { - Further additional devices, i.e., passive filters, were required to deal with } \\
\text { the power quality issues, mainly harmonics, generated by the extensive } \\
\text { adoption of VSDs in the plant. The cost of these additional devices is added } \\
\text { to the non-negligible cost of the EEM. } \\
\text { - Despite a rather long pay-back time according to the firm evaluation, the } \\
\text { economic assessment was positive. }\end{array}$} \\
\hline & & Total adoption cost & $\checkmark \checkmark$ & \\
\hline & & Adoption cost of secondary devices & $\checkmark \checkmark$ & \\
\hline & & $\begin{array}{l}\text { Adoption cost of additional } \\
\text { optimization de vices }\end{array}$ & $\checkmark$ & \\
\hline & & Financial exposure & $\mathrm{O}$ & \\
\hline & & \begin{tabular}{|l|} 
Monetary savings \\
\end{tabular} & $\checkmark$ & \\
\hline & & Pay-back time & $\checkmark$ & \\
\hline \multicolumn{3}{|l|}{ Energy benefits } & $\checkmark$ & • High energy consumption reduction. \\
\hline \multirow{12}{*}{$\begin{array}{l}\text { Production } \\
\text { related factors }\end{array}$} & \multirow{6}{*}{ Global } & Productivity - direct & $\checkmark \checkmark$ & \multirow{6}{*}{$\begin{array}{l}\text { - Productivity improvement is one of the main reasons driving the adoption } \\
\text { of the EEM. } \\
\text { - The indirect impacts on productivity were not considered by the decision- } \\
\text { maker. }\end{array}$} \\
\hline & & Productivity - indirect & $\mathrm{X}$ & \\
\hline & & Production quality - direct & $\mathrm{O}$ & \\
\hline & & Production quality - indirect & $\mathrm{X}$ & \\
\hline & & Production cost - direct & $\checkmark$ & \\
\hline & & Production cost - indirect & $\mathrm{X}$ & \\
\hline & \multirow{6}{*}{ Local } & Set-up time & $\checkmark$ & \multirow{6}{*}{$\begin{array}{l}\text { - The improvement in productivity derived from the increased reliability and } \\
\text { equipment lifetime, mainly due to the absence of brushes in the new devices, } \\
\text { was considered very important. } \\
\text { - The downtimes of the production for maintenance and repairs are reduced } \\
\text { thanks to the creation of an internal standard spare parts warehouse with } \\
\text { standard spare motors immediately available for use. }\end{array}$} \\
\hline & & Reliability & $\checkmark \checkmark$ & \\
\hline & & Downtime for maintenance and repair & $\checkmark \checkmark$ & \\
\hline & & Downtime for implementation & $\checkmark$ & \\
\hline & & Equipment lifetime & $\checkmark \checkmark$ & \\
\hline & & Improved process control & $\checkmark$ & \\
\hline \multirow{11}{*}{$\begin{array}{l}\text { Operations } \\
\text { related factors }\end{array}$} & \multirow{4}{*}{$\begin{array}{l}\text { Motor } \\
\text { conditions }\end{array}$} & Equipment temperature & $\checkmark$ & \multirow{4}{*}{$\begin{array}{l}\text { - The operations factors were considered, given their proximity to the } \\
\text { reliability of the equipment. In particular, the decision-maker noticed an } \\
\text { improvement in the air quality due to the absence of dust created by the DC } \\
\text { motors brushes degradation. }\end{array}$} \\
\hline & & \begin{tabular}{|l|} 
Equipment vibrations \\
\end{tabular} & $\checkmark$ & \\
\hline & & Equipment power quality & $\checkmark$ & \\
\hline & & Equipment air quality & $\checkmark$ & \\
\hline & \multirow{5}{*}{$\begin{array}{l}\text { Working } \\
\text { environment }\end{array}$} & Air quality & $\checkmark$ & \multirow{5}{*}{$\begin{array}{l}\text { - Except for the a forementioned air quality, the decision-maker did not take } \\
\text { into account variations in the working environment, nor the positive impact } \\
\text { this could have on the workers and on the conditions in which they are called } \\
\text { to operate, potentially indirectly fostering their productivity. }\end{array}$} \\
\hline & & Noise & $\mathrm{X}$ & \\
\hline & & Environmental temperature & $\mathrm{X}$ & \\
\hline & & Environmental vibrations & $\mathrm{X}$ & \\
\hline & & Health and safety & $\mathrm{X}$ & \\
\hline & \multirow{2}{*}{$\begin{array}{l}\text { External } \\
\text { environment }\end{array}$} & Waste & $\mathrm{O}$ & \multirow{2}{*}{$\begin{array}{l}\text { - Variations in the external environment were not considered, despite the } \\
\text { willingness of the firm to be perceived as sustainable and efficient, as } \\
\text { testified by the certificates they own and the events they organize. }\end{array}$} \\
\hline & & Emission & $\mathrm{O}$ & \\
\hline \multicolumn{3}{|l|}{ Synergies } & $\checkmark$ & - Synergies were considered \\
\hline \multirow{6}{*}{\multicolumn{2}{|c|}{ Complexity }} & Training & $\checkmark$ & \multirow{6}{*}{$\begin{array}{l}\text { - Complexity was mainly taken into account considering the dependency of } \\
\text { the EEM from other components, carefully analysed because of the } \\
\text { potentially disruptive effect it could have on a rigid system based on } \\
\text { production lines configuration. } \\
\text { - The complexity of the EEM required additional training for the operators. } \\
\text { - No accessibility issues were detected, despite AC motors are generally } \\
\text { larger with respect to DC ones and additional VSD had to be installed. }\end{array}$} \\
\hline & & $\begin{array}{l}\text { Dependency from other components/ } \\
\text { EEMs }\end{array}$ & $\checkmark$ & \\
\hline & & $\begin{array}{l}\text { Physical placement inside motor } \\
\text { system }\end{array}$ & $\checkmark$ & \\
\hline & & \begin{tabular}{|l} 
Activity type \\
\end{tabular} & $\checkmark$ & \\
\hline & & $\begin{array}{l}\text { Technical maturity and diffusion of } \\
\text { the technology in the market }\end{array}$ & $\checkmark$ & \\
\hline & & Accessibility & $\checkmark$ & \\
\hline & & Active personnel & $\checkmark$ & - Personnel was considered when dealing with the reduction in maintenance \\
\hline Personnel & Role & Passive personnel & $\mathrm{X}$ & $\begin{array}{l}\text { and referring to the additional training activities required by the EEM. } \\
\text { - The impacts on personnel who passively underwent changes in the } \\
\text { conditions of the working environment after the adoption of the EEM were } \\
\text { not considered. }\end{array}$ \\
\hline & & Active corporate involvement & $\checkmark$ & - Considering the investment and the extension of the EEM on 30 motors, \\
\hline & involvement & Passive corporate involvement & $\checkmark$ & $\begin{array}{l}\text { the adoption needed to be supported by higher management levels. } \\
\text { - A large number of employees was involved in the adoption of the EEM. }\end{array}$ \\
\hline & & Implementation type & $\checkmark$ & \\
\hline & & Check-up frequency & $\checkmark$ & \\
\hline Additional tecl & nical factors & Secondary devices necessary & $\checkmark$ & - The additional technical factors were considered by the decision-maker. \\
\hline & & Additional optimization devices & $\checkmark$ & \\
\hline & & Automation & $\checkmark$ & \\
\hline
\end{tabular}


In both the cases discussed in Table 5 and Table 6, the framework proved to be complete, being able to highlight all the important factors to be considered for the adoption of the EEMs. Interestingly, some of them were not always considered by the decision-makers of the two firms. Concerning EEM 2-1, many important factors that would support its adoption were assessed, however missing the most critical one highlighted in the present framework, i.e., lack of load compatibility, that effectively led to the EEM removal after its adoption. On the other hand, firm 3 was more aware of the adoption and, as the use of the framework showed, the large majority of factors that should have been considered were already assessed by their decision-maker. Nonetheless, the framework proved to shed light on some additional benefits which were overlooked by the firm (e.g., positive impacts on the working environment, thus on the personnel). While this addition would not change the outcome of the adoption, it could give a decision-maker a more realistic picture of the EEM adoption and its consequences. Therefore, the validation of the framework was successful in both cases.

Considering the whole sample of twelve EEMs, useful insights came from the validation process (Table 7). Firstly, the importance of all the categories and factors for in-depth decision-making about EEMs in EMS is confirmed. Regardless of the outcome of the adoption, by using the framework decision-makers confirmed they could undertake the assessment with additional valuable information on all the major factors. In particular, interviewees have appreciated the level of detail achieved by the framework that allowed for thorough decisionmaking over the specific EEMs. The efficacy of the approach has been shown multiple times during the interviews, e.g., in the case of firm 2 (EEM 2-1), where EEMs were not adopted because of the lack of compatibility with the existing system (see Table 5 for more details). However, the relevance of EEMs compatibility with the system in which they are adopted varies according to the specific technology; for instance, the compatibility with the applied load should be assessed for EMS but it might be less interesting for other technologies, e.g., lighting. As confirmed by respondents, with just a general framework to support decisionmakers, such specific implications could not be grasped. Moreover, the user-friendliness and ease of use of the framework, thanks to a perspective focused on the decision-maker, were particularly appreciated.

Secondly, the preliminary investigation revealed that the application of the framework would not have changed the decision of adopting the implemented EEMs: all the factors potentially driving the adoption were recognised by companies or, when not considered, they were mainly related to additional benefits (thus further corroborating the decision).

Thirdly, interviewees offered interesting insights and comments regarding not-implemented EEMs. As observed in many companies (e.g., Firm 5), firms could have implemented more valuable EEMs by using the framework, thus further improving their sustainability.

\section{Table 7}

Validation of the framework, pointing out: factors considered useful $(\checkmark)$ in the EEMs assessment; factors assessed and eventually driving the adoption decision, both positive (EEM implemented, $\checkmark \checkmark$ ) and negative 
(EEM not implemented, $\checkmark \checkmark *)$; factors neglected from the EEMs assessment, both negligible (O), important (X) and potentially reversing the decision $(\mathrm{XX})$ with respect to the outcome.

\begin{tabular}{|c|c|c|c|c|c|c|c|c|c|c|c|c|c|c|}
\hline \multicolumn{3}{|c|}{ Frame work } & \multicolumn{12}{|c|}{ Firms and EEMs } \\
\hline Coterrarios & Substenories & Foetom & EEM & EEM & EEM & EEM & EEM & EEM & EEM & EEM & EEM & EEM & EEM & EEM \\
\hline Categories & Sub-categones & Factors & $1-1$ & $1-2$ & $2-1$ & $2-2$ & $3-1$ & $3-2$ & $3-3$ & $4-1$ & $4-2$ & $5-1$ & $5-2$ & $6-1$ \\
\hline \multirow{6}{*}{\multicolumn{2}{|c|}{ Descriptive factors }} & Motor model & $\checkmark$ & $\checkmark$ & $\checkmark$ & $\checkmark$ & $\checkmark$ & $\checkmark$ & $\checkmark$ & $\checkmark$ & $\checkmark$ & $\checkmark$ & $\checkmark$ & $\checkmark$ \\
\hline & & Motor size & $\checkmark$ & $\checkmark$ & $\checkmark$ & $\checkmark$ & $\checkmark$ & $\checkmark$ & $\checkmark$ & $\checkmark$ & $\checkmark$ & $\checkmark$ & $\checkmark$ & $\checkmark$ \\
\hline & & Motors numerosity & $\checkmark$ & $\checkmark$ & $\checkmark$ & $\checkmark$ & $\checkmark$ & $\checkmark$ & $\checkmark$ & $\checkmark$ & $\checkmark$ & $\checkmark$ & $\checkmark$ & $\checkmark$ \\
\hline & & Working hours & $\checkmark$ & $\checkmark$ & $\checkmark$ & $\checkmark$ & $\checkmark$ & $\checkmark$ & $\checkmark$ & $\checkmark$ & $\checkmark$ & $\checkmark$ & $\checkmark$ & $\checkmark$ \\
\hline & & \begin{tabular}{|l|} 
Process focus \\
\end{tabular} & $\checkmark$ & $\checkmark$ & $\checkmark$ & $\checkmark$ & $\checkmark$ & $\checkmark$ & $\checkmark$ & $\checkmark$ & $\checkmark$ & $\checkmark$ & $\checkmark$ & $\checkmark$ \\
\hline & & Application load & $\checkmark$ & $\checkmark$ & $\checkmark$ & $\checkmark$ & $\checkmark$ & $\checkmark$ & $\checkmark$ & $\checkmark$ & $\checkmark$ & $\checkmark$ & $\checkmark$ & $\checkmark$ \\
\hline \multirow{4}{*}{ Compatibility } & \multirow[b]{2}{*}{ Load } & Load compatibility & $\checkmark$ & $\checkmark$ & $\mathrm{XX}$ & $\checkmark$ & $|\checkmark \checkmark *|$ & $\checkmark$ & $\checkmark$ & $\checkmark$ & $\checkmark$ & $\checkmark$ & $\checkmark$ & $\checkmark$ \\
\hline & & Adaptability to different conditions & $\checkmark \checkmark$ & $\checkmark$ & $\checkmark$ & $\checkmark$ & $\checkmark$ & \begin{tabular}{|l|l|}
$\checkmark \checkmark$ \\
\end{tabular} & $\checkmark$ & $\checkmark$ & $\checkmark$ & $\checkmark$ & $\checkmark$ & $\checkmark$ \\
\hline & \multirow[b]{2}{*}{ System } & Adaptability in every environment & $\checkmark$ & $\checkmark$ & $\checkmark$ & $\checkmark$ & $\mathrm{O}$ & $\mathrm{O}$ & $\mathrm{O}$ & $\checkmark$ & $\mathrm{X}$ & $\checkmark$ & $\checkmark$ & $\sqrt{ } \checkmark$ \\
\hline & & Reduced layout flexibility & $\mathrm{O}$ & $\checkmark$ & $\checkmark$ & $\checkmark$ & $\checkmark$ & $\checkmark$ & $\checkmark$ & $\checkmark$ & $\checkmark$ & $\checkmark$ & $\checkmark$ & $\mathrm{O}$ \\
\hline \multirow{7}{*}{\multicolumn{2}{|c|}{ Economy }} & Initial implementation cost & $\checkmark$ & $\checkmark \checkmark$ & $\checkmark \checkmark$ & $\checkmark \checkmark$ & $\checkmark$ & \begin{tabular}{|l|}
$\checkmark \checkmark$ \\
\end{tabular} & $\checkmark \checkmark$ & $\checkmark$ & $\checkmark \sqrt{ } *$ & $\checkmark \checkmark$ & $\checkmark \checkmark$ & $\checkmark \checkmark$ \\
\hline & & Total adoption cost & $\checkmark$ & $\checkmark \checkmark$ & $\overline{\checkmark \checkmark}$ & \begin{tabular}{|l|l|}
$\checkmark \checkmark$ \\
\end{tabular} & $\checkmark$ & \begin{tabular}{|l|l|}
$\checkmark \checkmark$ \\
\end{tabular} & $\begin{array}{ll}\checkmark \\
\end{array}$ & $\checkmark$ & $\checkmark \sqrt{ } *$ & $\checkmark \checkmark$ & $\checkmark \checkmark$ & $\checkmark \checkmark$ \\
\hline & & Adoption cost of secondary devices & $\mathrm{X}$ & $\mathrm{O}$ & $\mathrm{X}$ & $\checkmark$ & $\checkmark$ & $\checkmark \checkmark$ & $\checkmark$ & $\checkmark$ & $\checkmark \checkmark$ & $\mathrm{X}$ & $\mathrm{O}$ & $\checkmark$ \\
\hline & & $\begin{array}{l}\text { Adoption cost of add itional } \\
\text { optimization de vices }\end{array}$ & $\mathrm{X}$ & $\mathrm{O}$ & $\mathrm{O}$ & $\checkmark$ & $\checkmark$ & $\checkmark$ & $\checkmark$ & $\checkmark$ & $\checkmark$ & $\mathrm{X}$ & $\mathrm{O}$ & $\checkmark$ \\
\hline & & Financial exposure & $\mathrm{X}$ & $\mathrm{O}$ & $\mathrm{O}$ & $\mathrm{O}$ & $\mathrm{O}$ & $\mathrm{O}$ & $\mathrm{O}$ & $\checkmark$ & $\checkmark$ & $\mathrm{O}$ & $\mathrm{O}$ & $\mathrm{O}$ \\
\hline & & Monetary savings & $\checkmark \checkmark$ & $\checkmark \checkmark$ & $\checkmark$ & $\checkmark$ & $\checkmark \checkmark$ & $\checkmark$ & $\checkmark \checkmark$ & $\checkmark$ & $\checkmark$ & $\checkmark \checkmark *$ & $\checkmark \checkmark$ & $\checkmark \checkmark$ \\
\hline & & Pay-back time & $\checkmark$ & $\checkmark$ & $\checkmark \checkmark$ & $\checkmark$ & $\checkmark$ & $\checkmark$ & $\checkmark$ & $\checkmark$ & $\checkmark$ & $\checkmark$ & $\checkmark$ & $\checkmark$ \\
\hline \multicolumn{3}{|l|}{\begin{tabular}{|l|} 
Energy savings \\
\end{tabular}} & \begin{tabular}{|l|l|l|l|l|l}
$\checkmark \checkmark$ \\
\end{tabular} & $\checkmark \checkmark$ & $\checkmark$ & $\checkmark$ & $\checkmark \checkmark \mid$ & $\checkmark$ & $\checkmark \checkmark$ & $\checkmark$ & $\checkmark$ & $\checkmark \checkmark \mid$ & $\checkmark \checkmark \mid$ & $\checkmark \checkmark$ \\
\hline \multirow{12}{*}{$\begin{array}{l}\text { Production } \\
\text { related } \\
\text { factors }\end{array}$} & \multirow{6}{*}{ Global } & Productivity - direct & $\checkmark$ & $\checkmark$ & $\checkmark \checkmark$ & $\checkmark$ & $\checkmark \checkmark$ & $\checkmark \checkmark$ & $\checkmark$ & $\checkmark \checkmark$ & $\checkmark \checkmark$ & $\checkmark$ & $\checkmark$ & $\checkmark \checkmark$ \\
\hline & & Productivity - indirect & $\mathrm{O}$ & $\mathrm{O}$ & $\mathrm{O}$ & $\mathrm{X}$ & $\mathrm{O}$ & $\mathrm{X}$ & $\mathrm{X}$ & $\checkmark$ & $\mathrm{X}$ & $\mathrm{O}$ & $\mathrm{O}$ & $\checkmark$ \\
\hline & & Production quality - direct & $\checkmark$ & $\checkmark$ & $\checkmark$ & $\checkmark$ & $\checkmark$ & $\mathrm{O}$ & $\mathrm{O}$ & $\mathrm{O}$ & $\mathrm{O}$ & $\checkmark$ & $\checkmark$ & $\checkmark \checkmark$ \\
\hline & & Production quality - indirect & $\mathrm{O}$ & O & $\mathrm{O}$ & $X$ & 0 & $\mathrm{X}$ & $\mathrm{X}$ & $\checkmark$ & $\mathrm{X}$ & $\mathrm{O}$ & $\mathrm{O}$ & $\checkmark$ \\
\hline & & Production cost - direct & $\checkmark$ & $\checkmark$ & $\checkmark$ & $\checkmark$ & $\checkmark$ & $\checkmark$ & $\checkmark$ & $\checkmark$ & $\begin{array}{ll}\checkmark \\
\end{array}$ & $\checkmark$ & $\checkmark$ & $\sqrt{ } \checkmark$ \\
\hline & & Production cost - indirect & $\mathrm{O}$ & $\mathrm{O}$ & O & $\mathrm{X}$ & $\mathrm{O}$ & $\mathrm{X}$ & $\mathrm{X}$ & $\checkmark \checkmark$ & $\mathrm{X}$ & $\mathrm{O}$ & $\mathrm{O}$ & $\checkmark$ \\
\hline & \multirow{6}{*}{ Local } & Set-up time & $\checkmark$ & $\checkmark$ & $\checkmark$ & $\checkmark$ & $\mathrm{O}$ & $\checkmark$ & $\checkmark$ & $\checkmark$ & $\checkmark$ & $\checkmark$ & $\checkmark$ & $\checkmark$ \\
\hline & & Reliability of the equipment & $\checkmark$ & $\checkmark \checkmark$ & $\checkmark$ & $\checkmark \checkmark$ & $\checkmark \checkmark$ & $\checkmark \checkmark$ & $\checkmark$ & $\checkmark \checkmark$ & $\checkmark \checkmark$ & $\checkmark$ & $\checkmark$ & $\checkmark$ \\
\hline & & Downtime for maintenance and repair & $\mathrm{O}$ & $\mathrm{O}$ & $\checkmark$ & \begin{tabular}{|l|}
$\checkmark \checkmark$ \\
\end{tabular} & $\checkmark \checkmark$ & \begin{tabular}{|l|l|}
$\checkmark \checkmark$ \\
\end{tabular} & $\checkmark$ & $\checkmark$ & $\checkmark$ & $\checkmark$ & $\checkmark$ & $\checkmark$ \\
\hline & & \begin{tabular}{|l} 
Downtime for implementation \\
\end{tabular} & $\checkmark$ & $\checkmark$ & $\checkmark$ & $\checkmark$ & $\mathrm{O}$ & $\checkmark$ & $\checkmark$ & $\checkmark$ & $\checkmark$ & $\checkmark$ & $\checkmark$ & $\checkmark$ \\
\hline & & Equipment lifetime & $\checkmark$ & $\checkmark \checkmark$ & $\checkmark$ & $\checkmark$ & $\mathrm{O}$ & $\checkmark \checkmark$ & $\checkmark$ & $\checkmark \checkmark$ & $\begin{array}{ll}\checkmark \\
\end{array}$ & $\checkmark$ & $\checkmark$ & $\checkmark$ \\
\hline & & Process control & \begin{tabular}{|l|}
$\checkmark \checkmark$ \\
\end{tabular} & $\checkmark$ & $\overline{\checkmark \checkmark}$ & 0 & $\mathrm{O}$ & $\checkmark$ & $\begin{array}{ll}\checkmark \\
\end{array}$ & $\mathrm{O}$ & $\mathrm{O}$ & $\checkmark$ & $\checkmark$ & $\checkmark$ \\
\hline \multirow{11}{*}{$\begin{array}{l}\text { Operations } \\
\text { related } \\
\text { factors }\end{array}$} & & Equipment temperature & $\checkmark$ & $\checkmark$ & $\checkmark$ & $\checkmark$ & $\mathrm{O}$ & $\checkmark$ & $\checkmark$ & $\checkmark$ & $\bar{X}$ & $\checkmark$ & $\checkmark$ & $\checkmark \checkmark$ \\
\hline & & Equipment vibrations & $\checkmark$ & $\checkmark$ & $\checkmark$ & $\checkmark$ & $\mathrm{O}$ & $\checkmark$ & $\checkmark$ & $\checkmark$ & $\mathrm{X}$ & $\checkmark$ & $\checkmark$ & $\checkmark$ \\
\hline & Motor conditions & Equipment power quality & $\mathrm{X}$ & $\mathrm{O}$ & $\checkmark$ & $\checkmark$ & $\mathrm{O}$ & $\checkmark$ & $\checkmark$ & $\checkmark$ & $\mathrm{X}$ & $\checkmark$ & $\checkmark$ & $\checkmark$ \\
\hline & & Equipment air quality & $\mathrm{O}$ & $\checkmark$ & $\checkmark$ & $\checkmark$ & $\mathrm{O}$ & $\checkmark$ & $\checkmark$ & $\mathrm{O}$ & $\mathrm{X}$ & $\checkmark$ & $\checkmark$ & $\checkmark$ \\
\hline & & Air quality & $\mathrm{O}$ & $\checkmark$ & $\checkmark$ & $\checkmark$ & $\mathrm{O}$ & $\checkmark$ & $\checkmark$ & $\mathrm{O}$ & $\mathrm{X}$ & $\mathrm{O}$ & $\checkmark$ & $\checkmark$ \\
\hline & & Noise & $\mathrm{O}$ & $\checkmark$ & $\checkmark$ & $\checkmark$ & $\mathrm{O}$ & $\mathrm{X}$ & $\mathrm{X}$ & $\checkmark$ & $\mathrm{X}$ & $\mathrm{O}$ & $\checkmark$ & $\checkmark$ \\
\hline & Working environment & Environmental temperature & $\mathrm{O}$ & $\checkmark$ & $\checkmark$ & $\checkmark$ & $\mathrm{O}$ & $\mathrm{X}$ & $\mathrm{X}$ & $\checkmark$ & $\mathrm{X}$ & $\mathrm{O}$ & $\checkmark$ & $\checkmark$ \\
\hline & & \begin{tabular}{|l|} 
Environmental vibrations \\
\end{tabular} & $\mathrm{O}$ & $\checkmark$ & $\checkmark$ & $\checkmark$ & $\mathrm{O}$ & $\mathrm{X}$ & $\mathrm{X}$ & $\checkmark$ & $\mathrm{X}$ & $\mathrm{O}$ & $\checkmark$ & $\checkmark$ \\
\hline & & Health and safety & $\mathrm{O}$ & $\mathrm{O}$ & $\checkmark$ & $\checkmark$ & $\mathrm{O}$ & $\mathrm{X}$ & $\mathrm{X}$ & $\checkmark$ & $\bar{X}$ & $\mathrm{O}$ & $\checkmark$ & $\checkmark$ \\
\hline & lenvironment & Waste & $\mathrm{O}$ & $\mathrm{O}$ & 0 & $\mathrm{O}$ & 0 & $\mathrm{O}$ & $\mathrm{O}$ & $\checkmark$ & $\mathrm{O}$ & $\checkmark$ & $\checkmark$ & $\checkmark$ \\
\hline & 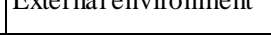 & Emission & $\mathrm{O}$ & $\mathrm{O}$ & $\mathrm{O}$ & $\mathrm{O}$ & $\mathrm{O}$ & $\mathrm{O}$ & $\mathrm{O}$ & $\checkmark$ & $\mathrm{O}$ & $\checkmark$ & $\checkmark$ & $\checkmark$ \\
\hline Synergies & & & $\mathrm{X}$ & $\checkmark$ & $\mathrm{O}$ & $\mathrm{O}$ & $\mathrm{O}$ & $\checkmark$ & $\checkmark$ & $\mathrm{O}$ & $\mathrm{O}$ & $\checkmark$ & $\checkmark$ & $\mathrm{O}$ \\
\hline & & Training & $\checkmark$ & $\checkmark$ & $\checkmark$ & $\checkmark$ & $\mathrm{O}$ & $\checkmark$ & $\checkmark$ & $\checkmark \checkmark$ & $\checkmark \sqrt{ } *$ & $\checkmark$ & $\checkmark$ & $\checkmark \checkmark$ \\
\hline & & $\begin{array}{l}\text { Dependency from other components/ } \\
\text { EEMs }\end{array}$ & $\checkmark$ & $\checkmark$ & $\checkmark$ & $\checkmark$ & $\mathrm{O}$ & $\checkmark \checkmark$ & $\checkmark \checkmark$ & $\checkmark$ & $\checkmark$ & $\checkmark$ & $\checkmark$ & $\checkmark \checkmark$ \\
\hline Comnlexity & & \begin{tabular}{|l|} 
Physical placement inside motor system \\
\end{tabular} & $\checkmark$ & $\checkmark$ & $\checkmark$ & $\checkmark$ & $\mathrm{O}$ & $\checkmark$ & $\checkmark$ & $\checkmark$ & $\checkmark$ & $\checkmark$ & $\checkmark$ & $\checkmark$ \\
\hline Complexity & & Activity type & $\checkmark$ & $\checkmark$ & $\checkmark$ & $\checkmark$ & $\mathrm{O}$ & $\checkmark$ & $\checkmark$ & $\checkmark$ & $\checkmark$ & $\checkmark$ & $\checkmark$ & $\checkmark$ \\
\hline & & $\begin{array}{l}\text { Technical maturity and diffusion of the } \\
\text { technology in the market }\end{array}$ & $\checkmark$ & $\checkmark$ & $\checkmark$ & $\checkmark$ & $\mathrm{O}$ & $\checkmark \checkmark$ & $\checkmark$ & $\checkmark$ & $\checkmark$ & $\checkmark$ & $\checkmark$ & $\mathrm{O}$ \\
\hline & & \begin{tabular}{|l|} 
Accessibility \\
\end{tabular} & $\mathrm{O}$ & $\mathrm{O}$ & $\checkmark$ & $\checkmark$ & $\mathrm{O}$ & $\checkmark$ & $\checkmark$ & $\checkmark \checkmark$ & $\checkmark \checkmark$ & $\checkmark$ & $\checkmark$ & $\checkmark$ \\
\hline & & Active personnel & $\checkmark$ & $\checkmark$ & $\checkmark$ & $\checkmark$ & $\mathrm{O}$ & $\checkmark$ & $\checkmark$ & $\checkmark$ & $\checkmark$ & $\checkmark$ & $\checkmark$ & $\checkmark \checkmark$ \\
\hline Perconnel & Role & Passive personnel & $\checkmark$ & $\checkmark$ & $\checkmark$ & $\mathrm{X}$ & $\mathrm{O}$ & $\mathrm{X}$ & $\mathrm{X}$ & $\checkmark$ & $\mathrm{X}$ & $\mathrm{O}$ & $\checkmark$ & $\checkmark$ \\
\hline Personnel & & Active corporate involvement & $\checkmark$ & $\checkmark$ & $\checkmark$ & $\checkmark$ & $\mathrm{O}$ & $\mathrm{X}$ & $\mathrm{X}$ & $\checkmark$ & $\checkmark$ & $\checkmark$ & $\checkmark$ & $\checkmark$ \\
\hline & Corporate involvemer & Passive corporate involvement & $\checkmark$ & $\checkmark$ & $\checkmark$ & $\mathrm{X}$ & $\mathrm{O}$ & $\mathrm{X}$ & $\mathrm{X}$ & $\checkmark$ & $\mathrm{X}$ & $\mathrm{O}$ & $\checkmark$ & $\checkmark$ \\
\hline & & Implementation type & $\checkmark$ & $\checkmark$ & $\checkmark$ & $\checkmark$ & $\mathrm{O}$ & $\checkmark$ & $\checkmark$ & $\checkmark$ & $\checkmark$ & $\checkmark$ & $\checkmark$ & $\checkmark$ \\
\hline & & Check-up frequency & $\checkmark$ & $\checkmark$ & $\checkmark$ & $\checkmark$ & $\mathrm{O}$ & $\checkmark$ & $\checkmark$ & $\checkmark$ & $\checkmark$ & $\checkmark$ & $\checkmark$ & $\checkmark$ \\
\hline Additional tech & hnical factors & Secondary devices necessary & $\mathrm{X}$ & $\mathrm{O}$ & $\mathrm{X}$ & $\checkmark$ & $\mathrm{O}$ & $\checkmark$ & $\checkmark$ & $\checkmark$ & $\checkmark$ & $\mathrm{X}$ & $\mathrm{O}$ & $\checkmark$ \\
\hline & & Additional optimization devices & $\mathrm{X}$ & $\mathrm{O}$ & $\mathrm{X}$ & $\checkmark$ & $\mathrm{O}$ & $\checkmark$ & $\checkmark$ & $\checkmark$ & $\checkmark$ & $\mathrm{X}$ & $\mathrm{O}$ & $\checkmark$ \\
\hline & & Automation & $\checkmark$ & $\checkmark$ & $\checkmark$ & $\checkmark$ & $\mathrm{O}$ & $\checkmark$ & $\checkmark$ & 0 & $\checkmark$ & $\mathrm{O}$ & $\mathrm{O}$ & $\mathrm{O}$ \\
\hline
\end{tabular}




\section{Discussion}

The empirical analysis performed in the present study confirmed the criticality played by some of the factors previously identified by literature and summarised in Table 1. Productivity improvements, achieved through the higher reliability of the new equipment, drove the adoption of EEM 1-2 and EEM 2-2, confirming findings from previous works that linked the adoption of EEMs to increased productivity [39,112]. Productivity and process control improvements also led firm 2 to the consideration of a VSD (EEM 2-1), confirming the finding of Saidur et al. [141]. In Firm 4, reliability represented the main driver for the EEMs considered by firm 4, confirming the importance attributed to the factor by previous research (e.g., Gordon et al. [49]). In accordance, the literature demonstrated how reliability is important for both increasing the value offered by a firm and decreasing its operational risk [31,53]. Furthermore, operations related factors were assessed by all decision-makers interviewed, especially in the case of EEM 6-1, where the equipment temperature was a factor of primary importance. Indeed, impacts on factors such as air quality, vibrations and temperature show a strict connection with the equipment performance. Such finding looks aligned with those of Piette and Nordman [76], who highlighted a degradation in both the production quality and the reliability of the equipment as a consequence of the variation of those factors. Furthermore, earlier literature greatly supported the role of EEMs as a means to affect the working environment, with a consequent impact on workers comfort, health and safety, and indirectly on their productivity [39]. From the interviews performed in the present study, these factors were not always assessed by decision-makers, which however acknowledged their relevance by using the framework. Also, our preliminary investigation showed that the external environment, encompassing emissions and waste factors, was either largely neglected or barely relevant for the adoption. However, when dealing with environmental topics, respondents clearly pointed out their firms were fully compliant with local regulations, and this could explain the relatively lower importance attributed to these factors. Our findings differ from other research where the impact on the external environment was crucial for the decision [64,82], in particular when dealing with industrial firms subjected to environmental regulations. Lilly and Pearson [65] showed how the evaluation of emissions is different depending on whether firms may incur fines, whilst Elliott et al. [33] pointed out that emissions could be even more important than any enhancement in reliability or production since unfulfilled regulations could lead to a complete shutdown of the firms' operations.

Nevertheless, despite the great importance attributed to the aforementioned categories of factors, the present research shows additional categories and factors playing a key role in the adoption of EEMs in EMS. The present investigation revealed how some additional factors, specific for EMS, should be pinpointed for more effective decision-making, critical since often neglected by literature and sometimes even by decision-makers. This the case of e.g., the factors related to the compatibility or the complexity dimensions of an EEM, especially when EEMs in EMS may affect the core production processes. According to our results (e.g., EEM 2.1 and EEM 3.1), compatibility issues might prevent decision-makers from implementing those EEMs, regardless of any further consideration or achievable benefits. Our empirical findings corroborate previous works linking 
complexity and compatibility of innovation and the respective level of adoption [16,17]. However, referring to the broad concept of innovation, previous analyses lack the level of detail necessary for an empirical assessment of EMS EEMs, being rather focused on compressed air systems [75]. Nevertheless, being the compressed air systems an ancillary service, important considerations that might play a critical role for EMS were not captured (e.g., the need to adapt to the variation of production conditions, as shown by EEM 1-1 or EEM 3-2). Likewise, our investigation broad new knowledge about other important factors (e.g., synergies, the impacts on personnel or the additional technical factors) previously mostly overlooked by research [36].

Earlier literature gave limited importance to the specific context of application of the EEMs (e.g., the location [32] or the distance to the core process [12,13,31]). Rather, the investigated case studies revealed that the EMS EEMs should be analysed within their specific context of application. As noted in firm 2, the lack of compatibility identified was due to both the technical characteristics of the EEM [113] and the context in which the EEM was meant to operate.

Moreover, the case studies made it possible to observe the impact of contextual factors. For instance, motors' size and numerosity seem to have a moderating function (similarly to what observed by Aguinis et al. [142]) on other factors, e.g., the investment cost. For firm 4, e.g., the higher cost due to large motor size and high number represented one of the main issues hindering the replacement of the old DC motors. Furthermore, the same contextual factors might affect the importance attributed to the external and working environment, since these may not be significantly affected in the case of just a few small motors installed. As observed in firm 5 (EEM 51), despite the great importance of the working environment conditions, this feature was overlooked because of the limited size of the motor proposed for the intervention $(3.5 \mathrm{KW})$ and its limited number of working hours. Furthermore, the preliminary investigation seems to point out that the type of load may also have a moderating function on monetary energy savings - when the EEM refers to a controller [143,144] -, and decision-makers seemed particularly sensitive to this effect every time a VSD was considered for application. Differently, the process centrality seems to be characterized by a mediating nature [142], particularly evident when looking at the different critical elements by analysing core versus ancillary processes. Core processes represent the main activity of the plant, therefore extremely connected to revenues and market competitiveness: hence, it is reasonable to expect the adoption of EMS EEMs to be primarily led by productivity enhancement and the related factors, e.g., reliability [31,61]. Rather, similar patterns cannot be clearly identified for ancillary processes. Likewise, energy intensity plays an important role in affecting firms' behaviour [53]. According to the literature, given the high share of energy costs, energy-intensive firms are usually more concerned about energy savings [96,99]. The findings of the present study show that earlier approaches limited on technical and costeffectiveness analyses of EEMs (e.g., [145,146]) are not sufficient to justify the adoption in, e.g., non-energy intensive firms [53], where the influence on the production and the operations shall be carefully analysed. Our study also confirms earlier findings referring to the impact of the firm size on the adoption process due to the lack of procedures and internal competencies [147,148]. Indeed, in the greatest majority of case studies 
regarding SMEs, the analysis performed by the intervie wees did not include all the factors that should be taken into account for thorough decision-making (see Table 6). On the other hand, in larger sampled firms a higher degree of awareness was observed, possibly related to the lower level of energy management and interest in energy issues that generally characterize smaller firms [99], which in turn is reflected in lower expertise when it comes to adopting EEMs. Consequently, the proposed framework appears particularly suitable for SMEs to support them in identifying the major factors when adopting EEMs in EMS.

\section{Conclusions}

The present study aims at offering a contribution to the discussion over industrial energy efficiency by offering an innovative framework for the identification and assessment of the major factors driving the adoption of EEMs in EMS. Besides assessing the technical, economic and energy-related characteristics of EEMs [113], the framework has been designed to encompass their specific context of application and their impacts on the production resources and the firm's operations. The framework thus obtained is inclusive of fifty-four factors, organized into ten categories, representing the minimum information to take sound decisions regarding the adoption of EEMs in EMS. The preliminary investigation in a set of manufacturing enterprises operating in various contexts demonstrated the capability to provide increased knowledge to industrial decision-makers. In particular, decision-makers belonging to non-energy intensive firms could make valuable use of the framework, given its capability to pinpoint interesting impacts across the energy dimension to provide a more comprehensive view of the adoption. Similarly, the framework emerged particularly suitable for SMEs, which may experience greater difficulties in gathering information about EEMs. In addition, the proposed framework could support policy-makers in identifying the major barriers preventing the adoption of EEMs in EMS. In fact, by highlighting the major factors, more specific and tailored policies could address the specific issues at the backbone of the decision-making process of adopting an EEM. Nevertheless, more research is needed in this direction.

In conclusion, a limitation of the study should be acknowledged referring to the size of the validation sample, which prevents a statistical generalization of findings. Future research should test the framework on a wider set of firms and their respective sectors, to allow for the statistical significance of the findings. Similarly, the number of tested EEMs should be increased to better understand how they impact different areas of an industrial firm. Furthermore, the moderating and mediating role [142] of some factors was just preliminarily observed (e.g., firm size or energy intensity), but future research should more thoroughly and more extensively shed light on these relationships. Also, another interesting yet challenging research avenue stemming from the study is represented by the quantification of the impacts deriving from the adoption of EEMs in EMS.

\section{Appendix}

Table A.1 
Preliminary validation of the framework in terms of usefulness, completeness, clearness and classification, evaluated through a Likert scale from one(poor) to four (excellent).

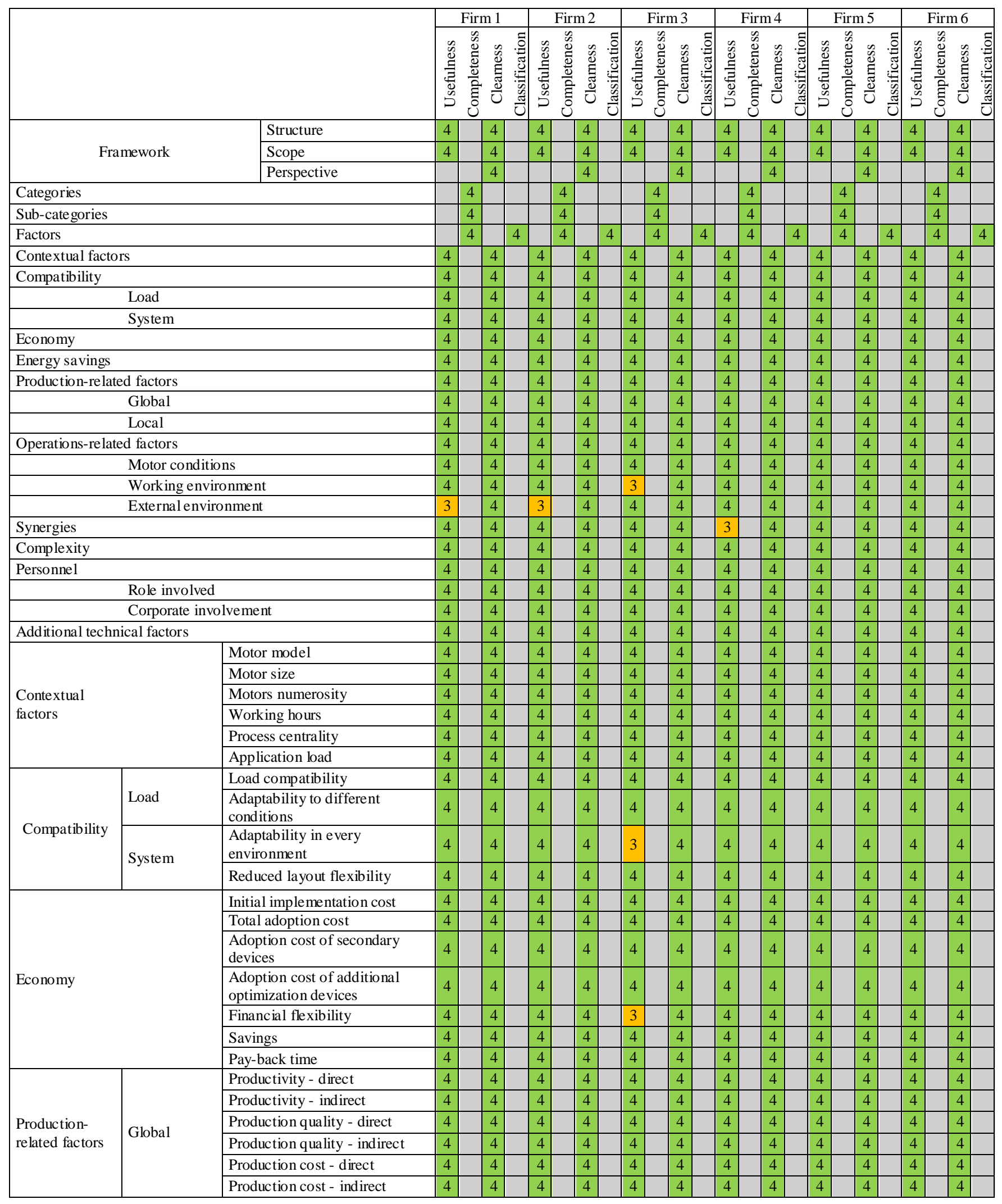




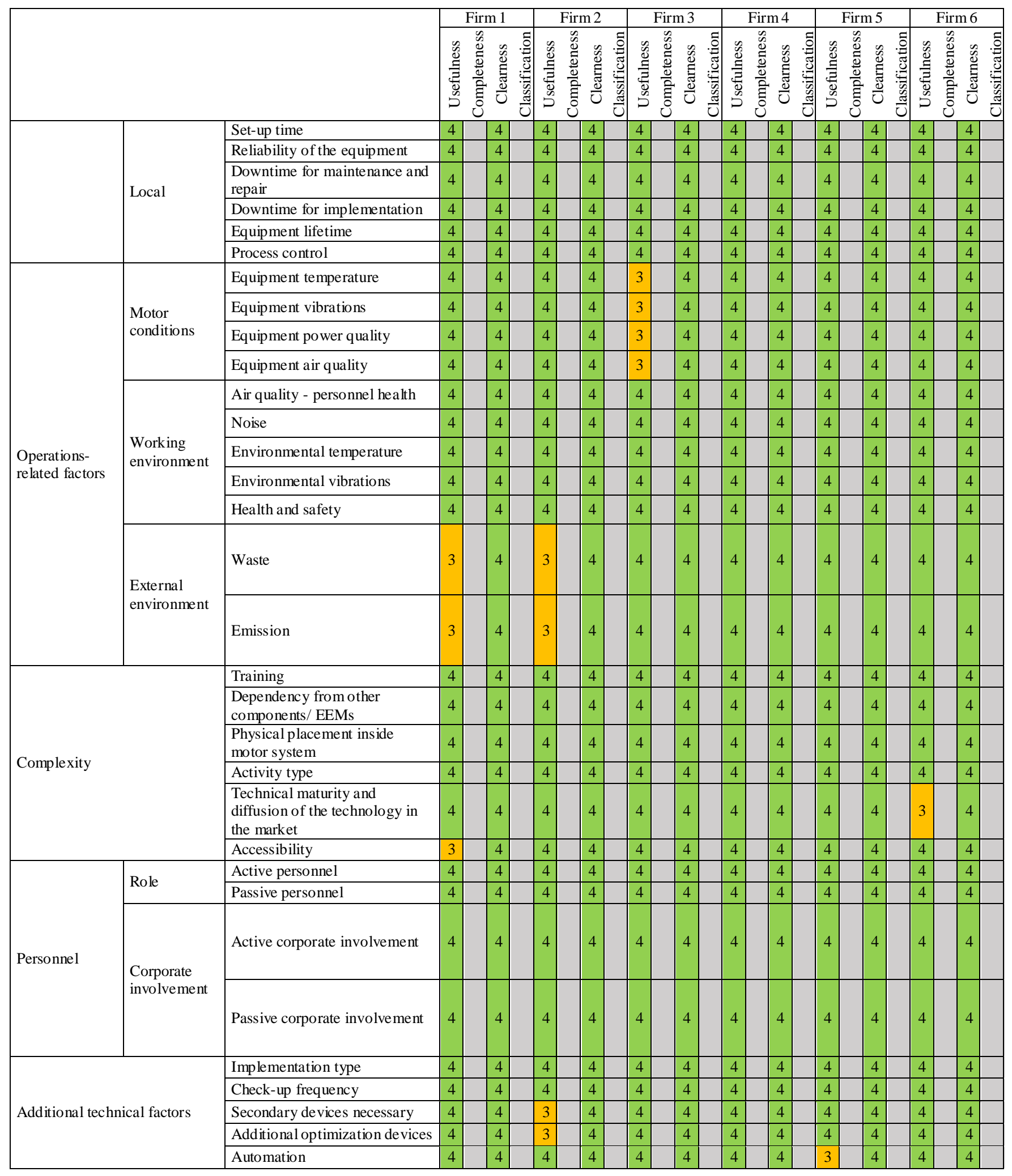

\section{Funding}

This research did not receive any specific grant from funding agencies in the public, commercial, or not-forprofit sectors. 


\section{References}

[1] U.S. Department of Energy. International Energy Outlook 2019 with projections to 2050. Washington, DC, USA: U.S. Department of Energy; 2019; p. 85 .

[2] International Energy Agency. Energy Efficiency 2O18-Analysis and outlooks to 2040; Market Report Series. Paris, France: OECD/IEA; 2018; p.174.

[3] International Energy Agency. 2018 World Energy Outlook—Executive Summary. Paris, France: OECD/IEA; 2018 ; p. 11.

[4] Energetics Incorporated. Manufacturing Energy and Carbon Footprint, All Manufacturing. Washington, DC, USA: U.S. Department of Energy; 2014.

[5] Confindustria. Rapporto efficienza energetica. Roma, Italy: Confindustria; 2017; p. 21. Italian.

[6] Saidur R. A review on electrical motors energy use and energy savings. Renew Sustain Energy Rev 2010;14:877-98.

[7] Jaffe AB, Stavins RN. The Energy-efficiency Gap - What does it mean? Energy Policy 1994;22:804-10.

[8] Waide P, Brunner CU. Energy-Efficiency Policy Opportunities for Electric Motor-Driven Systems. Paris, France: OECD/IEA; 2011.

[9] Industrial Assessment Center (IAC) Database. Available online: https://iac.university/download (accessed 18 December 2020).

[10] Thollander P, Ottosson M. An energy efficient Swedish pulp and paper industry - Exploring barriers to and driving forces for cost-effective energy efficiency investments. Energy Effic 2008;1:21-34.

[11] Rohdin P, Thollander P. Barriers to and driving forces for energy efficiency in the non-energy intensive manufacturing ind ustry in Sweden. Energy 2006;31:1836-44.

[12] Fleiter T, Hirzel S, Worrell E. The characteristics of energy-efficiency measures - a neglected dimension. Energy Policy 2012;51:502-13.

[13] Trianni A, Cagno E, De Donatis A. A framework to characterize energy efficiency measures. App1 Energy 2014;118:207-20.

[14] Muller, M.R.; Pasi, S.; Baber, K.; Landis, S. Industrial Assessment Center-Assessment Recommendation Code. Washington, DC, US A: U.S. Department of Energy; 2019; p. 44.

[15] U.S. Department of Energy: Advanced Manufacturing Office. Improving Motor and Drive System Performance: A sourcebook for Industry. Washington, DC, US A: U.S. Department of Energy; 2008; p. 177.

[16] Rogers EM. Diffusion of innovations. 3rd ed. New York: Collier Macmillan Publishers; 2019.

[17] Tornatzky LG, Klein KJ. Innovation Characteristics and Innovation Adoption- Implementation : A Meta-Analysis of Findings. IEEE Trans Eng Manag 1982;EM-29:28-45.

[18] Anderson ST, Newell RG. Information programs for technology adoption: The case of energy-efficiency audits. Resour Energy Econ 2004;26:27-50.

[19] Sandberg P, Soderstrom M. Industrial energy efficiency : the need for investment decision support from a manager perspective. Energy Policy 2003;31:1623-34.

[20] Hellström T. Dimensions of Environmentally Sustainable Innovation : the Structure of Eco-Innovation Concepts. Sustain Dev 2007;15:148-59.

[21] Mills E, Kromer S, Weiss G, Mathew PA. From volatility to value: Analysing and managing financial and performance risk in energy savings projects. Energy Policy 2006;34:188-99.

[22] Liu X, Niu D, Bao C, Suk S, Shishime T. A survey study of energy saving activities of industrial companies in Taicang, China. J Clean Prod 2012;26:79-89.

[23] Millar HH, Russell SN. The adoption of sustainable manufacturing practices in the Caribbean. Bus Strateg Environ 2011;20:512-26.

[24] Office of Technology Assessment. Industrial Energy Efficiency. U.S. Congress. Washington, DC: U.S. Government Printing Office; 1993.

[25] Thollander P, Palm J. Improving energy efficiency in Industrial Energy Systems. An interdisciplinary Perspective on Barriers, Energy Audits, Energy Management, Policies and programs. 1th ed. Berlin: Springer; 2013.

[26] Therkelsen P, McKane A. Implementation and rejection of ind ustrial steam system energy efficiency measures. Energy Policy 2013;57:318-28.

[27] Trianni A, Cagno E, Worrell E, Pugliese G. Empirical investigation of energy efficiency barriers in Italian manufacturing SMEs. Energy 2013;49:444-58.

[28] Woodruff MG, Jones TW, Dowd J, Roop JM, Seely HE, Muller MR. Evidence from the industrial assessment program on energy investment decisions by small and medium-sized manufacturers. Proceedings of the Thirty-Second Intersociety Energy Conversion Engineering Conference, Honolulu, HI, USA, 27 July-1 August 1997;2138-42.

[29] Thollander P, Ottosson M. Energy management practices in Swedish energy-intensive ind ustries. J Clean Prod 2010;18:1125-33.

[30] Backlund S, Ottosson M, Broberg S. Energy efficiency potentials and energy management practices in Swedish firms. Proceedings of the eceee Summer Study on energy efficiency in industry: 30 percent of Europe's energy use, Arnhem, the Netherlands, 11-14 Sep 2012;5:669-77. Cooremans C. Make it strategic! Financial investment logic is not enough. Energy Effic 2011;4:473-92.

[32] Roberts SJF, Ball PD. Developing a library of sustainable manufacturing practices. Proceedings of the 5th CIRP Conference on Assembly Technologies and Systems, Dresden, Germany, 13-14 November 2014;15:159-64.

[33] Elliott RN, Laitner S, Pye M. Considerations in the estimation of costs and benefits of ind ustrial energy efficiency projects. Proceedings of the Thirty-Second Intersociety Energy Conversion Engineering Conference, Honolulu, HI, USA, 27 July-1 August 1997;3:2143-47.

[34] Skumatz LA, Gardner J. Methods and results for measuring non-energy benefits in the commercial and industrial sectors. Proceedings of the ACEEE Summer Study on Energy Efficiency in Industry: Cutting the High Cost of Energy. West Point, New York, USA, 2005;6:163-76.

[35] Pye M, McKane A. Making a stronger case for industrial energy efficiency by quantifying non-energy benefits. Resour Conserv Recycl 2000;28:171-83.

[36] Cagno E, Moschetta D, Trianni A. Only non-energy benefits from the adoption of energy efficiency measures? A novel framework. J Clean Prod 2019;212:1319-33.

[37] Skumatz LA, Dickerson CA, Coates B. Non-energy benefits in the residential and non-residential sectors: Innovative measurements and results for participant benefits. Proceedings of the ACEEE Summer Study on Energy Efficiency in Buildings: Energy Efficiency \& Sustainability, Pacific Grove, CA, USA, 17-21 August 2000;8:353-364.

[38] Mills E, Rosenfelds ART. Consumer non-energy benefits as a motivation for making energy-efficiency improvements. Energy 1996;21:707-20. [39] Worrell E, Laitner JA, Ruth M, Finman H. Productivity be nefits of industrial energy efficiency measures. Energy 2003;28:1081-98.

[40] Porter ME, Van Der Lind C. Toward a New Conception of the Environment-Competitiveness Relationship. J Econ Perspect 1995;9:97-118.

[41] Rohdin P, Thollander P, Solding P. Barriers to and drivers for energy efficiency in the Swedish foundry industry. Energy Policy 2007;35:672-7.

[42] Lung RB, Mckane A, Leach R, Marsh D. Ancillary Savings and Production Benefits in the Evaluation of Industrial Energy Efficiency Measures. Proceedings of the ACEEE Summer Study on Energy Efficiency in Industry: Cutting the High Cost of Energy. West Point, New York, USA, 2005;6:103-114.

[43] González PR. Analysing the factors influencing clean technology adoption: A study of the Spanish pulp and paper industry. Bus Strateg Environ 2005;14:20-37. 
[44] Ryan L, Campbell N. Spreading the Net: the Multiple Benefits of Energy Efficiency Improvements. Paris, France: OECD/IEA; 2012.

[45] Finman H, Laitner JA. Industry, Energy Efficiency and Productivity Improvement. Proceedings of the ACEEE Summer Study on Energy Efficiency in Industry, New York, US A, 24-27 July 2001;1:561-570.

[46] Nehler T, Thollander P, Ottosson M, Dahlgren M. Including non-energy benefits in investment calculations in industry - Empirical findings from Sweden. Proceedings of the Eceee Industrial Summer Study: Retool for a competitive and sustainable industry, Arnhem, the Netherlands, 2-5 June 2014;2:711-719.

[47] Nehler T. Linking energy efficiency measures in industrial compressed air systems with non-energy benefits - A review. Renew Sustain Energy Rev 2018;89:72-87.

[48] Skumatz LA. Non-Energy Benefits/Non-Energy Impacts (NEBs/NEIs) and their Role \& values in Cost-Effectiveness Tests: State of Maryland. Superior (CO): Skumatz Economic Research Associates; 2014.

[49] Gordon F, Peters J, Harris J, Scales B. Why is the treasure still buried? Breaching the barriers to compressed air system efficiency. Proceedings of the 3rd ACEEE Summer Study on Energy Efficiency in Indus-try: Industry and Innovation in the 21 st Century, New York, US A, 15-18 June 1999; 709-718.

[50] Christiansen IS, Gudbjerg E, Dyhr-Mikkelsen K. New robes for NEB research - Open and expanding data. Proceedings of the Eceee Industrial Summer Study: Going beyond energy effic iency to deliver savings, competitiveness and a circular economy, Berlin, Germany, 12-14 September $2016 ; 3: 417-26$.

[51] Rasmussen J. Energy-efficiency investments and the concepts of non-energy benefits and investment behaviour. Proceedings of the Eceee Industrial Summer Study: Retool for a competitive and sustainable industry, Arnhem, the Netherlands, 2-5 June 2014;2:733-44.

[52] Laitner JA, Ruth M, Worrell E. Incorporating the Productivity Benefits into the Assessment of Cost-effective Energy Savings Potential Using Conservation Supply Curves. Proceedings of the ACEEE Summer Study on Energy Efficiency in Industry, New York, US A, 24-27 July 2001;1:597-608.

[53] Killip AG, Cooremans C, Fawcett T. Multiple benefits of energy efficiency. D2.2 Guidelines for Protocols, Interventions and Evaluations. 2018. Contract No.: 785131. Sponsored by the European Union's Horizon 2020 research and innovation programme.

[54] Doyle F, Cosgrove J. An approach to optimising compressed air systems in production operations. Int J Ambient Energy 2018;39:194-201.

[55] Lung B, Nimbalkar S, Wenning T. Multiple Benefits of Industrial Energy Efficiency - Lessons Learned and New Initiatives. Proceedings of the Industrial Energy Technology Conference, New Orleans, LA, USA, 18-20 June 2019. Available online at https://www.osti.gov/servlets/pur1/1531223.

[56] Russell C. What's in it for the chief financial officer?: The financial dynamics of corporate energy management. Strateg Plan Energy Environ 2009;29:53-66.

[57] Pearson D, Skumatz L a. Non-Energy Benefits Including Productivity, Liability, Tenant Satisfaction, and Others : What Participant Surveys Tell Us about Designing and Marketing Commercial Programs. Proceedings of the ACEEE Summer Study on Energy Efficiency in Buildings, Washington, DC, 18-23 August 2002;4:289-302.

[58] Skumatz LA, Dickerson CA. Extra! Extra! Non-Energy Benefits Swamp Load Impacts For PG\&E Program! Proceedings of the ACEEE Summer Study on Energy Efficiency in Buildings: Energy Efficiency in a Competitive Environment, Pacific Grove, CA, USA, 12-17 August 1998;8:30112.

[59] Anderson KJ, Collins B, Cortese A, Ekman A. Summary of Results for Six Industrial Market Transformation Projects. Funded by the Northwest Energy Efficiency Alliance. Proceedings of the ACEEE Summer Study on Energy Efficiency in Industry, New York, US A, 24-27 July 2001;1:255-266.

[60] Bicknell C, Skumatz LA. Non-Energy Benefits ( NEBs ) in the Commercial Sector: Results from Hundreds of Buildings. Proceedings of the ACEEE Summer Study on Energy Efficiency in Buildings, 2007;4:10-22.

[61] Russell C. Multiple Benefits of Business-Sector Energy Efficiency: A Survey of Existing and Potential Measures. Washington, DC, USA: ACEEE; 2015.

[62] Ilomäki M, Melanen M. Waste minimization in small and medium-sized enterprises - do environmental management systems help? J Clean Prod 2001;9:209-17.

[63] Martin N, Worrell E, Ruth M, Price L, Elliott RN, Shipley AM, et al. Emerging energy-efficient industrial technologies. Berkeley (CA): Lawrence Berkeley National Laboratory, Environmental Energy Technologies Division; 2000. Contract No.: DE-AC03-76SF00098. Sponsored by the Department of Energy.

[64] Hall N, Roth J. Non-Energy Benefits from Commercial \& Industrial Programs: What Are the Benefits and Why Are They Important to Participants? Proceedings of the ACEEE Summer Study on Energy Efficiency in Buildings: Breaking out of the box, Pacific Grove, USA, 22-27 August 2004;4:123-135.

[65] Lilly P, Pearson D. Determining the full value of industrial efficiency programs. Proceedings of the 3rd ACEEE Summer Study on Energy Efficiency in Industry: Industry and Innovation in the 21st Century, New York, US A, 15-18 June 1999; 349-362.

[66] Carbon Trust. Motors and Drives - Introducing Energy Saving Opportunities for Business. London, UK: The Carbon Trust; $2018 ;$ p. 5.

[67] Motor Decision Matter. Motor Planning Kit - Strategies, Tools and Resources for Developing a Comprehensive Motor Management Plan. Boston, MA: Motor Decisio Matter; 2007.

[68] Cagno E, Trianni A. Analysis of the most effective energy efficiency opportunities in manufacturing primary metals, plastics, and textiles smalland medium-sized enterprises. J Energy Resour Technol Trans ASME 2012;134:1-9.

[69] Nehler T, Parra R, Thollander P. Implementation of energy efficiency measures in compressed air systems: barriers, drivers and non-energy benefits. Energy Effic 2018;11:1281-302.

[70] Trianni A, Cagno E. Dealing with barriers to energy efficiency and SMEs: Some empirical evidences. Energy 2012;37:494-504.

[71] Cooremans C. Investment in energy efficiency: Do the characteristics of investments matter? Energy Effic 2012;5:497-518.

[72] Cagno E, Worrell E, Trianni A, Pugliese G. A novel approach for barriers to industrial energy efficiency. Renew Sustain Energy Rev 2013;19:290-308.

[73] International Energy Agency. Accelerating Energy Efficiency in Small and Medium-sized Enterprises. Powering SMEs to catalyse economic growth. Paris, France: OECD/IEA; 2015.

[74] Nehler T, Thollander P, Fredriksson L, Friberg S, Nordberg T. Non-energy benefits of Swedish energy efficiency policy instruments - A threelevelled perspective. Proceedings of the Eceee Industrial Summer Study, Berlin, Germany, 11-13 June 2018;1:139-49.

[75] Trianni A, Accordini D, Cagno E. Identification and Categorization of Factors Affecting the Adoption of Energy Efficiency Measures within Compressed Air Systems. Energies 2020;13:1-51.

[76] Piette MA, Nordman B. Costs and Benefits from Utility- Funded Commissioning of Energy- Efficiency Measures in 16 Buildings. Proceedings of the ASHRAE Winter Meeting, Atlanta, GA, US A, 17-21 February 1996. 
benefits: "core" benefits are highly probable and worth a double-digit improvement to energy savings. Energy Eng J Assoc Energy Eng 2012;109:7-26.

[78] Lazar J, Colburn K. Recognizing the Full Value of Energy Efficiency. Montpelier, VT, USA: RAP; 2013. Available online at www.raponline.org.

[79] Bozorgi A. Integrating value and uncertainty in the energy retrofit analysis in real estate investment-next generation of energy efficiency assessment tools. Energy Effic 2015;8:1015-34.

[80] Cooremans C. Competitiveness benefits of energy efficiency : a conceptual framework. Proceedings of the Eceee summer study, Toulon, France, 1-6 June 2015;123-31.

[81] International Energy Agency. Capturing the Multiple Benefits of Energy Efficiency. Paris, France: OECD/IEA; 2014. p. 232.

[82] Nehler T, Rasmussen J. How do firms consider non-energy benefits? Empirical findings on energy efficiency investments in Swedish industry. J Clean Prod 2016;113:472-82.

[83] Rasmussen J. The additional benefits of energy efficiency investments - a systematic literature review and a framework for categorisation. Energy Effic 2017;10:1401-18.

[84] Nehler T. A systematic literature review of methods for improved utilisation of the non-energy benefits of industrial energy efficiency. Energies 2018;11:6-8.

[85] Stevens N, Foley L, Weber S, Rathbun P, Goldberg M. Using In-depth Interview to Estimate Non-energy Impacts Resulting from Commercial and Industrial Energy Efficiency Measures Tin \# 1 : Consumer Marketing and Intelligence. New Hampshire Public Utilities Commission. Available online at https://www.puc.nh. gov/EESE\%20Board/Meetings/2017/021017EERSWorkshop1/Using\%20Indepth\%20Interview\%20to\%20Estimate\%20Non-energy\%20Impacts.pdf

[86] Parra R, Thollander P, Nehler T. Barriers to, drivers for and non-energy benefits for industrial energy efficiency improvement measures in compressed air systems. Proceedings of the Eceee Industrial Summer Study: Going beyond energy efficiency to deliver savings, competitiveness and a circular economy, Berlin, Germany, 12-14 September 2016;2:293-304.

[87] Gudbjerg E, Dyhr-Mikkelsen K, Andersen CM. Spreading the word - An online non-energy benefit tool. Proceedings of the Eceee Industrial Summer Study: Retool for a competitive and sustainable industry, Arnhem, the Netherlands, 2-5 June 2014;1:171-8.

[88] Kamal A, Al-Ghamdi SG, Koc M. Revaluing the costs and benefits of energy efficiency: A systematic review. Energy Res Soc Sci 2019;54:6884.

[89] Worrell E, Angelini T, Masanet E. Managing Your Energy. An ENERGY STAR Guide for Identifying Energy Savings in Manufacturing Plants. Berkeley (CA): Lawrence Berkeley National Laboratory, Environmental Energy Technologies Division; 2010. Contract No.: DE-AC02 05CH11231. Sponsored by the U.S. Environmental Protection Agency.

[90] Bunse K, Vodicka M, Schönsleben P, Brülhart M, Ernst FO. Integrating energy efficiency performance in production management - Gap analysis between industrial needs and scientific literature. J Clean Prod 2011;19:667-79.

[91] Sauter R, Volkery A. Review of Costs and Benefits of energy savings. London: Institute for European Environmental Policy; 2013.

[92] Reuter M, Eichhammer W. A decision support tool for energy efficiency policy evaluation. Odyssee-Mure; 2017. Contract No.: H2020 Energy/69607. Sponsored by the European Union's Horizon 2020 program.

[93] Reuter M, Patel MK, Eichhammer W, Lapillonne B, Pollier K. A comprehensive indicator set for measuring multiple benefits of e nergy efficiency. Energy Policy 2020;139:111284.

[94] Vine E. Addressing non-energy benefits in the cost-effectiveness framework. California Public Utilities Commission; 2011. Available online at https://library.cee1.org/system/files/library/9734/CEE_EvalNEBCostEffect.pdf

[95] Skumatz LA. Efficiency Programs' Non-Energy Benefits: How States Are Finally Making Progress in Reducing Bias in Cost-Effectiveness Tests. Electr J 2015;28:96-109.

[96] Mills E, Shamshoian G, Blazek M, Naughton P, Seese RS, Tschudi W, et al. The business case for energy management in high-tech industries. Energy Effic 2008;1:5-20.

[97] Kasprowicz R, Schulz C. Availability-based payback method for energy efficiency measures. Proceedings of the twenty-second CIRP conference on life cycle engineering, 2015;29:710-5.

[98] Ferreira FJTE, Baoming G, de Almeida AT. Reliability and operation of high-efficiency induction motors. IEEE Trans Ind App1 2016;52:462837.

[99] Cooremans C, Schönenberger A. Energy management: A key driver of energy-efficiency investment? J Clean Prod 2017;230:264-75.

[100] Imbierowicz K, Skumatz La. The Most Volatile Non-Energy Benefits (NEBs): New Research Results “ Homing In " on Environmental And Economic Impacts. Proceedings of the ACEEE Summer Study on Energy Efficiency in Buildings: Breaking out of the box, Pacific Grove, USA, 22-27 August 2004:156-67.

[101] Smith-McClain L, Skumatz LA, Gardner J. Attributing NEB Values to Specific Measures: Decomposition Results from Programs with Multiple Measures. Proceedings of the ACEEE Summer Study on Energy Efficiency in Buildings, Pacific Grove, USA, 13-18 August 2006;2:264-73.

[102] Skumatz L, Gardner J. Differences in the Valuation of Non-Energy Benefits According to Measurement Methodology: Causes and Consequences. Proceedings of the Association for Energy Service Professionals NESP Conference, January 2006, US A. Available online at http://library.aesp.org/resources/Docuworks/file_display.cfm?id=421

[103] Bement D, Skumatz LA. New Non-Energy Benefits (NEBs) results in the commercial/industrial sectors: Findings from incentive, retrofit, and technical assistance/new construction programs. Proceedings of the eceee summer study on energy efficiency, France, 4-9 june 2007;7:1551-9.

[104] Finster MP, Hernke MT. Benefits organizations pursue when seeking competitive advantage by improving environmental performance. J Ind Ecol 2014;18:652-62.

[105] Worrell E, Martin N, Price L, Ruth M, Elliott N, Shipley AM, et al. Emerging energy-efficient technologies for industry. Energy Eng 2002;99:36-55.

[106] Vine E, Mills E, Chen A. Energy-efficiency and renewable energy options for risk management and insurance loss reduction. Energy 2000;25:131-47.

[107] Imbierowicz K, Skumatz LA, Gardner J. Net NEB Multipliers for Economic Impacts: Detailed Analysis of Differences by Program Type and State. Proceedings of the ACEEE Summer Study on Energy Efficiency in Buildings, Pacific Grove, USA, 13-18 August 2006;5:169-77.

[108] Schweitzer M, Tonn B. Non-energy benefits of the US Weatherization Assistance Program: A summary of their scope and magnitude. Appl Energy $2003 ; 76: 321-35$.

[109] Tonn B, Peretz JH. State-level benefits of energy efficiency. Energy Policy 2007;35:3665-74.

[110] Krutwig MC, Starosta KD. Characterization, classification and assessment of non-energy benefits of energy efficiency measures. Proceedings of the thirty International Business Information Management Association Conference Madrid, Spain, 8-9 November 2017;2697-707.

[111] Zhang S, Worrell E, Crijns-Graus W, Wagner F, Cofala J. Co-benefits of energy efficiency improvement and air pollution abatement in the Chinese iron and steel industry. Energy 2014;78:333-45. 
[112] Boyd GA, Pang JX. Estimating the linkage between energy efficiency and productivity. Energy Policy 2000;28:289-96.

[113] Trianni A, Cagno E, Accordini D. Energy efficiency measures in electric motors systems: A novel classification highlighting specific implications in their adoption. Appl Energy 2019;252:113481.

[114] Cagno E, Accordini D, Trianni A. A framework to characterize factors affecting the adoption of energy efficiency measures within electric motors systems. Proceedings of the 10th International Conference on Applied Energy, Hong Kong, China, 22-25 August 2018;158:3352-7.

[115] DeCanio SJ. Barriers within firms to energy-efficient investments. Energy Policy 1993;21:906-14.

[116] Trianni A, Cagno E. Diffusion of Motor Systems Energy Efficiency Measures: An Empirical Study Within Italian Manufacturing SMEs. Proceedings of the 7th International Conference on Applied Energy, Abu Dhabi, UAE 28-31 March 2015;75:2569-74.

[117] De Almeida AT, Fonseca P, Bertoldi P. Energy-efficient motor systems in the industrial and in the services sectors in the European Union: Characterisation, potentials, barriers and policies. Energy 2003;28:673-90.

[118] Saidur R, Rahim NA, Ping HW, Jahirul MI, Mekhilef S, Masjuki HH. Energy and emission analysis for industrial motors in Malaysia. Energy Policy 2009;37:3650-8.

[119] Lu SM. A review of high-efficiency motors: Specification, policy, and technology. Renew Sustain Energy Rev 2016;59:1-12.

[120] De Almeida A, Fong J, Brunner CU, Werle R, Van Werkhoven M. New technology trends and policy needs in energy efficient motor systems A major opportunity for energy and carbon savings. Renew Sustain Energy Rev 2019;115:109384.

[121] Motor Challenge Fact Sheet. Replacing an Oversized and Underloaded Electric Motor. Washington, DC, US A: U.S. Department of Energy; 2014.

[122] Motor Challenge Fact Sheet. Buying an Energy-Efficient Elecrtic Motor. Washington, DC, USA: U.S. Department of Energy; 2014.

[123] U.S. Department of Energy DOE. Replace V-Belts with Notched or Synchronous Belt Drives. Mot Syst Tip Sheet \#5. Washington, DC, USA: U.S. Department of Energy, Advanced Manufacturing Office; 2012.

[124] Sorrell S, Schleich J, Scott S, O'Malley E, Trace F, Bode U, et al. Reducing barriers to energy efficiency in private and public organisations. University of Sussex, Falmer, UK: Science Policy Research Unit SPRU; 2000; p. 197.

[125] Venmans F. Triggers and barriers to energy efficiency measures in the ceramic, cement and lime sectors. J Clean Prod 2014;69:133-42.

[126] Trianni A, Cagno E, Farnè S. An empirical investigation of barriers, drivers and practices for energy efficiency in primary metals manufacturing SMEs. Proceedings of the 6th International Conference on Ap-plied Energy, Taipei, Taiwan, 30 May-2 June 2014;61:1252-1255

[127] Abdelaziz EA, Saidur R, Mekhilef S. A review on energy saving strategies in industrial sector. Renew Sustain Energy Rev 2011;15:150-68.

[128] Saidur R, Rahim NA, Masjuki HH, Mekhilef S, Ping HW, Jamaluddin MF. End-use energy analysis in the Malaysian industrial sector. Energy 2009;34:153-8

[129] Sa A, Thollander P, Cagno E. Assessing the driving factors for energy management program adoption. Renew Sustain Energy Rev 2017;74:53847.

[130] Worrell E, Biermans G. Move over ! Stock turnover , retrofit and industrial energy efficiency. Energy Policy 2005;33:949-62

[131] Worrell E, Price L. Policy scenarios for energy efficiency improve ment in industry. Energy Policy 2001;29:1223-41.

[132] Brown MA. Market failures and barriers as a basis for clean energy policies. Energy Policy 2001;29:1197-207.

[133] Hirst E, Brown M. Closing the efficiency gap: barriers to the efficient use of energy. Resour Conserv Recycl 1990;3:267-81.

[134] Wulfinghoff DR. Energy efficiency manual: for everyone who uses energy, pays for utilities, controls energy usage, designs and builds, is interested in energy and environmental preservation. London: Energy Institute Press; 1999.

[135] Yin R. Case Study Research: Design and Methods. fifth edit. New York: Sage Publications; 2013

[136] Voss C, Tsikriktsis N, Frohlich M. Case research in operations management. Int J Oper Prod Manag 2002;22:195-219.

[137] Cagno E, Trianni A, Spallina G, Marchesani F. Drivers for energy efficiency and their effect on barriers: empirical evidence from Italian manufacturing enterprises. Energy Effic 2017;10:855-69.

[138] Eurostat. Gross domestic product (GDP) at current market prices by NUTS 2 regions. Luxembourg: Eurostat; 2021. Available online at https://ec.europa.eu/eurostat/databrowser/bookmark/33395a81-3e9f-4b2d-8f37-f6803bd68b81?lang=en

[139] Bernard HR. Research Methods in Anthropology: Qualitative and Quantitative Approaches. Fourth ed. Lanham, MD: Rowman Altamira; 2006; p. 680.

[140] Russell CH. Energy management pathfinding: Understanding manufacturers' ability and desire to implement energy efficiency. Strateg Plan Energy Environ 2009;25:20-54.

[141] Saidur R, Mekhilef S, Ali MB, Safari A, Mohammed HA. Applications of variable speed drive (VSD) in electrical motors energy savings. Renew Sustain Energy Rev 2012;16:543-50.

[142] Aguinis H, Edwards JR, Bradley KJ. Improving Our Understanding of Moderation and Mediation in Strategic Management Research. Organ Res Methods 2017;20:665-85.

[143] National Electric Manufacturer Association. Application Guide For AC Adjustable Speed Drive Systems. Rosslyn: National Electric Manufacturer Association NEMA; 2001.

[144] Carbon Trust. Variable speed drives - Introducing energy saving opportunities for business. London, UK: The Carbon Trust; 2007.

[145] Gómez JR, Quispe EC, del Pilar Castrillón R, Viego PR. Identification of technoeconomic opportunities with the use of premium efficiency motors as alternative for developing countries. Energies 2020;13:5411.

[146] De Almeida AT, Ferreira FJTE, Both D. Technical and economical considerations in the application of variable speed drives with electric motor systems. Conf Rec Ind Commer Power Syst Tech Conf 2004;41:136-44.

[147] Cagno E, Trianni A. Evaluating the barriers to specific industrial energy efficiency measures: An exploratory study in small and medium-sized enterprises. J Clean Prod 2014;82:70-83.

[148] Johansson I, Mardan N, Cornelis E, Kimura O, Thollander P. Designing policies and programmes for improved energy efficiency in industrial SMEs. Energies 2019;12:1338. 